\title{
A bibliometric review of the innovation adoption literature
}

\begin{abstract}
Innovation adoption is of utmost importance for company survival. That is why it is important to develop a thorough understanding of this research domain and the themes it encapsulates. Since the early work of Everett Rogers, the adoption of innovation literature has attracted considerable attention and has continued to grow rapidly, resulting in a large but fragmented body of literature. The goal of this study is to provide a coherent overview of the theoretical cornerstones as well as recent research trends in the innovation adoption literature. To this end, we conducted a bibliometric review and performed bibliographic coupling and co-citation analysis. First, based on co-citation analysis, we illustrate that innovation adoption research is built on four theoretical cornerstones including: institutional theory; theory of reasoned action; theory concerning the determinants of adoption, and; diffusion theory. Second, bibliographic coupling was used to assess the current research trends. This review is the first to identify thematic areas in an exhaustive manner revealing five clusters of thematic related publications or "research trends": determinants of IT adoption; adoption of technological standards; organizational rationales associated with adoption; modelling diffusion, and; adoption of agricultural innovations. We conclude this review with the limitations and future research orientations in the field of innovation adoption.
\end{abstract}

\section{Keywords:}

Innovation adoption; Literature Review; Bibliographic Coupling; Co-citation Analysis

\section{Highlights:}

- Adoption and diffusion research is highly segregated

- Innovation adoption research builds upon 4 theoretical cornerstones

- Current innovation adoption research can be linked to 5 "research trends"

- Theoretical cornerstones and trends frame the relevance of future adoption research 


\section{INTRODUCTION}

Many scientific publications in the field of innovation research start from the premise that innovation contributes to a firm's competitive advantage and is considered a necessity for firm survival.

Adoption-diffusion literature can be traced to the work of Gabriel Tarde, a French sociologist, who introduced the Laws of Imitation at the beginning of the 1900s [1]. However, not until Everett Rogers [2] introduced the Diffusion of Innovations Theory (DOI) did adoption and diffusion research gain widespread recognition. Rogers conceptualized innovation adoption as a communication process whereby adoption reflects a pattern of information flow about an innovation. We start from the semantic work of Rogers [3] to assess the innovation adoption literature.

A number of arguments speak for the theoretical and practical relevance of producing a review on the adoption of innovation. First, the innovation adoption literature has continued to grow rapidly since these early works which resulted in a large but also fragmented body of literature [4-6]. Second, as have been addressed by Gupta et al. [4] and Keupp et al. [6], innovation literature is organised in specific domains. While adoption research entered a wide variety of sectors within the economy [3], the understanding of innovation adoption has grown considerably building on theoretical insights from innovation, organizational and behavioural centred theories. It has been suggested that a "schools of thought" approach might be a prominent path bringing together existing knowledge and theories [11]. Third, as have been emphasized in previous reviews [6, 7], innovation research in the past decades has failed to deliver clear and consistent findings, coherent advice to managers, and convincing "best practice” solutions so far.

The aim of this article is to present a bibliometric review of the innovation adoption literature. In particular, we aim to 1) identify the theoretical foundations of innovation 
adoption, 2) pinpoint current themes in adoption of innovation research, and 3) identify avenues for future research. By helping innovation adoption scholars to understand better the key cornerstones of this field of research, the direction in which it is developing and by pointing to potential research gaps, our study is intended to provide a guideline for scholars in positioning their future research efforts. Therefore, we focused on two questions. First, what are the key theoretical cornerstones of innovation adoption research? Second, what are the current research trends within the field of innovation adoption? The first research question involves a classification of scientific articles which revealed four theoretical cornerstones including: A) Institutional Theory and the legitimization of innovative behaviour; B) Theory of Reasoned Action and the Technology Acceptance Model; C) The determinants of innovation adoption through an econometric perspective; and D) Diffusion Theory. For the second research question we assessed the same cited references and identified five trending research directions including: 1) Drivers and impediments of information technology adoption; 2) The adoption of technology standards; 3) Organizational rationales associated with innovation adoption; 4) Modelling the diffusion process; and 5) Adoption of agricultural innovations.

The most recent influential innovation adoption review dates from the 2003 review by Greenhalgh et al [8]. Since then, novel bibliometric methods have been developed to review the literature. Bibliometric studies have already shown their usefulness in a broad array of management research, including innovation $[9,10]$. Bibliometric reviews differ from highly cited reviews in this field [13,19,20,21,22], on the aspects data, analysis and coverage [11]. A key benefit of bibliometric methods is their ability to help reduce reviewers' subjectivity and bias, which are inherent to conventional qualitative reviews [12]. In contrast to respected and highly cited reviews in the field, our bibliographic study of the innovation adoption field is based on quantitative data rather than qualitative interpretations which tend to reflect the 
subjective views of the authors $[10,11,13]$. This article presents a bibliometric review of the innovation adoption research over the period 2003-2016.

In combining two techniques, co-citation analysis and bibliographic coupling, we visualize the network of publications on innovation adoption and arrive at distinct clusters of thematically related publications. This quantitative review allowed us to create a more systematic and encompassing picture of the adoption innovation research agenda, especially in terms of theoretical foundations and avenues for future research.

This article is structured in the following way. In the section that follows, Section 2, we discuss the method we applied to this review and present the articles included. In Section 3, the theoretical cornerstones of innovation adoption research are discussed; in Section 4, we consider recent debates on innovation adoption research. Section 5 discusses the key findings of this review and elaborates about the potential paths for future research.

\section{DATA AND METHODS}

\subsection{Data}

For our two bibliometric analyses, we follow the four-step procedure as outlined by Kovacs et al. [14]. First, we developed a search query for the Web of Science (WoS) database (-Core Collection). We included articles using the terms: “innovation [and] adoption”. We restricted our search to articles published between 2003 and 2016. We chose this time span because our preliminary analysis of the available review articles and meta-analysis studies indicated that the most influential literature reviews were at least three years old. A preliminary search resulted in the identification of approximately 6,800 articles. To further narrow down our search, only articles from the WoS Research Area "Business Economics” were included in the review, since our primary interest is in the mechanisms that affect innovation adoption from an innovation economics viewpoint. In-depth analysis of this refinement revealed that 
top innovation journals and the most cited articles were not excluded from the review (see Figure 2). Moreover, many of the articles that were excluded by this refinement addressed the status quo of a certain kind of "development" - describing them as innovative is questionable - without contributing to the development of innovation adoption theory itself. As a result, application of these selection criteria resulted in 3,713 articles that could be reviewed in greater depth.

Second, to ensure that each article in this study was relevant to the adoptioninnovation domain, the abstract, key words, and introductory section were manually evaluated by the authors. This allowed us to exclude false positives, i.e. articles that include the terms "innovation" and "adoption" in the title, abstract, or keywords but are unrelated to the domain under study (see, for example, [15]). We did not remove articles that were indirectly related to the innovation adoption debate, e.g. articles that focus on implementation and assimilation of innovations. These articles could well enrich the review and in case they are irrelevant to the domain under study they appear in the periphery of the visual map created with the Vos Viewer software. Applying the aforementioned selection criteria resulted in a set of 1,260 articles (with 45,932 references) to be included in the bibliometric review. For each of the 1,260 articles, an output file (tab-delimited) was generated from the WoS database. The cited references are relevant for this bibliographic review and formed the raw input for the VOS Viewer software.

Third, we analysed the WoS data of the remaining 1,260 articles using the VOS Viewer software. Two types of output were generated: a co-citation analysis of cited references and bibliographic coupling of the 1,260 articles identified. The VOS Viewer identified 1,260 articles suitable for bibliographic coupling, that together have 45,932 cited references of which 155 have a minimum of 20 citations. Figures 1 and 2 present descriptive statistics of this dataset. 
During the fourth and final step, we interpreted the results of the co-citation analyses and the bibliometric coupling. To interpret and label the theoretical orientations of each cluster, all articles were downloaded from the Web of Science database and all books were accessed via the university library. The co-citation analysis of cited references was used to derive the theoretical cornerstones of innovation adoption research (Clusters A, B,C, and D). The output of the bibliographic coupling analysis allowed us to define the thematic clusters (Clusters 1, 2, 3, 4 and 5). Clusters A-D encompass a limited number of articles; therefore, the assessment of these clusters was relatively straightforward. However, each cluster, 1 to 5, holds up to 300 articles, making interpretation and labelling a less straightforward process. Therefore, for each cluster, the fifteen most cited articles were identified. However, since these articles could be situated on the periphery of a specific cluster, the 15 articles that are most closely related to each other were identified based on a cluster's density plot. The density view corresponds with the label view (figure 6) with the difference that the labels are now expressed by a colour scheme. The colour scheme (blue-green-red) depends on the density of items at that point, i.e. the colour at a certain point is calculated by the number of items in the vicinity of that point as well as on the importance of the neighbouring items [13]. The authors independently labelled the clusters after which the results were discussed to find an agreed label for each cluster. The theoretical cornerstones and current research trends identified will be discussed in Sections 3 and 4 respectively. The validity of any bibliometric review depends in part on the selection of publications that form the input of the analyses. Although the journals included in WoS Core Collection meet the highest standards regarding impact factor and number of citations [10, 16], we decided to further evaluate the robustness of our bibliometric review by using the Scopus database. This 
allowed us to verify if we omitted relevant studies that could have affected our core findings. ${ }^{1}$

Our search queries in the WoS and Scopus database resulted in 2,216 and 2,706 articles

respectively. This difference is in part explained by a difference in the search queries used. In

WoS the query was limited to the research area of 'business economics'. In Scopus this filter

is not available and therefore we included articles linked to the two Scopus categories

'business management' and 'economics'. By comparing the search results we observe that

1,088 articles are included in both output files, i.e. a $49 \%$ and $40 \%$ overlap with the WoS and

Scopus data set respectively. As a next step we ran a separate co-citation analysis using the

Scopus output file with VOS Viewer software. Examination of the two bibliometric maps

revealed that both maps can be linked to the same theoretical cornerstones. From this we

conclude that our findings are robust and not specific to the WoS database.

Table 1: Most cited review, overview and meta-analysis articles on adoption of innovation (based on the Web of Science citations linked to Google Scholar search results).

\begin{tabular}{|c|c|c|c|c|c|}
\hline $\mathrm{Nr}$ & Authors & Title & Citations & Type & Field \\
\hline 1 & $\begin{array}{l}\text { Venkatesh et al. (2003) } \\
\text { [17] }\end{array}$ & $\begin{array}{l}\text { User acceptance of information technology: } \\
\text { Toward a unified view }\end{array}$ & 3,925 & Survey & ICT innovation \\
\hline 2 & $\begin{array}{l}\text { Damanpour (1991) } \\
\text { [18] }\end{array}$ & $\begin{array}{l}\text { Organizational innovation - A meta-analysis } \\
\text { of effects of determinants and moderators }\end{array}$ & 1,706 & $\begin{array}{l}\begin{array}{l}\text { Meta- } \\
\text { analysis }\end{array} \\
\end{array}$ & $\begin{array}{l}\text { Organizational } \\
\text { innovation }\end{array}$ \\
\hline 3 & $\begin{array}{l}\text { Greenhalgh et al. } \\
\text { (2003) [8] }\end{array}$ & $\begin{array}{l}\text { Diffusion of innovation in service } \\
\text { organizations: Systematic review and } \\
\text { recommendations }\end{array}$ & 1,724 & Review & $\begin{array}{l}\text { Health care } \\
\text { innovation }\end{array}$ \\
\hline 4 & $\begin{array}{l}\text { Legris et al. (2003) } \\
\text { [19] }\end{array}$ & $\begin{array}{l}\text { Why do people use information technology? } \\
\text { A critical review of the technology } \\
\text { acceptance model }\end{array}$ & 713 & Review & ICT innovation \\
\hline 5 & $\begin{array}{l}\text { Tornatzky and Klein } \\
\text { (1982) [20] }\end{array}$ & $\begin{array}{l}\text { Innovation characteristics and innovation } \\
\text { adoption-implementation - a meta-analysis } \\
\text { of findings }\end{array}$ & 709 & $\begin{array}{l}\text { Meta- } \\
\text { analysis }\end{array}$ & $\begin{array}{l}\text { Not sector } \\
\text { specific }\end{array}$ \\
\hline 6 & Feder et al. (1985) [21] & $\begin{array}{l}\text { Adoption of agricultural innovations in } \\
\text { developing countries }\end{array}$ & 604 & Survey & $\begin{array}{l}\text { Agricultural } \\
\text { innovation }\end{array}$ \\
\hline 7 & Geroski (2000) [22] & Models of technology diffusion & 386 & Survey & $\begin{array}{l}\text { Not sector } \\
\text { specific }\end{array}$ \\
\hline 8 & $\begin{array}{lr}\text { Gatignon and } \\
\text { Robertson (1985) [23] }\end{array}$ & $\begin{array}{l}\text { A propositional inventory for new diffusion } \\
\text { research }\end{array}$ & 360 & Review & $\begin{array}{l}\text { Not sector } \\
\text { specific }\end{array}$ \\
\hline 9 & Wolfe (1994) [24] & $\begin{array}{l}\text { Organizational innovation - review, critique } \\
\text { and suggested research directions }\end{array}$ & 343 & Review & $\begin{array}{l}\text { Organizational } \\
\text { innovation }\end{array}$ \\
\hline 10 & $\begin{array}{lr}\text { Frambach } & \text { and } \\
\text { Schillewaert } & (2002) \\
\text { [25] } & \\
\end{array}$ & $\begin{array}{l}\text { Organizational innovation adoption }- \text { a } \\
\text { multi-level framework of determinants and } \\
\text { opportunities for future research }\end{array}$ & 247 & Review & $\begin{array}{l}\text { Organizational } \\
\text { innovation }\end{array}$ \\
\hline
\end{tabular}

${ }^{1}$ The EBSCO Academic Search Complete database deemed not suitable for this purpose as it excludes relevant innovation journals and includes grey literature that we did not want include in our analyses. Furthermore this database did not permit us to limit our search query to our focus area of 'business economics'. 


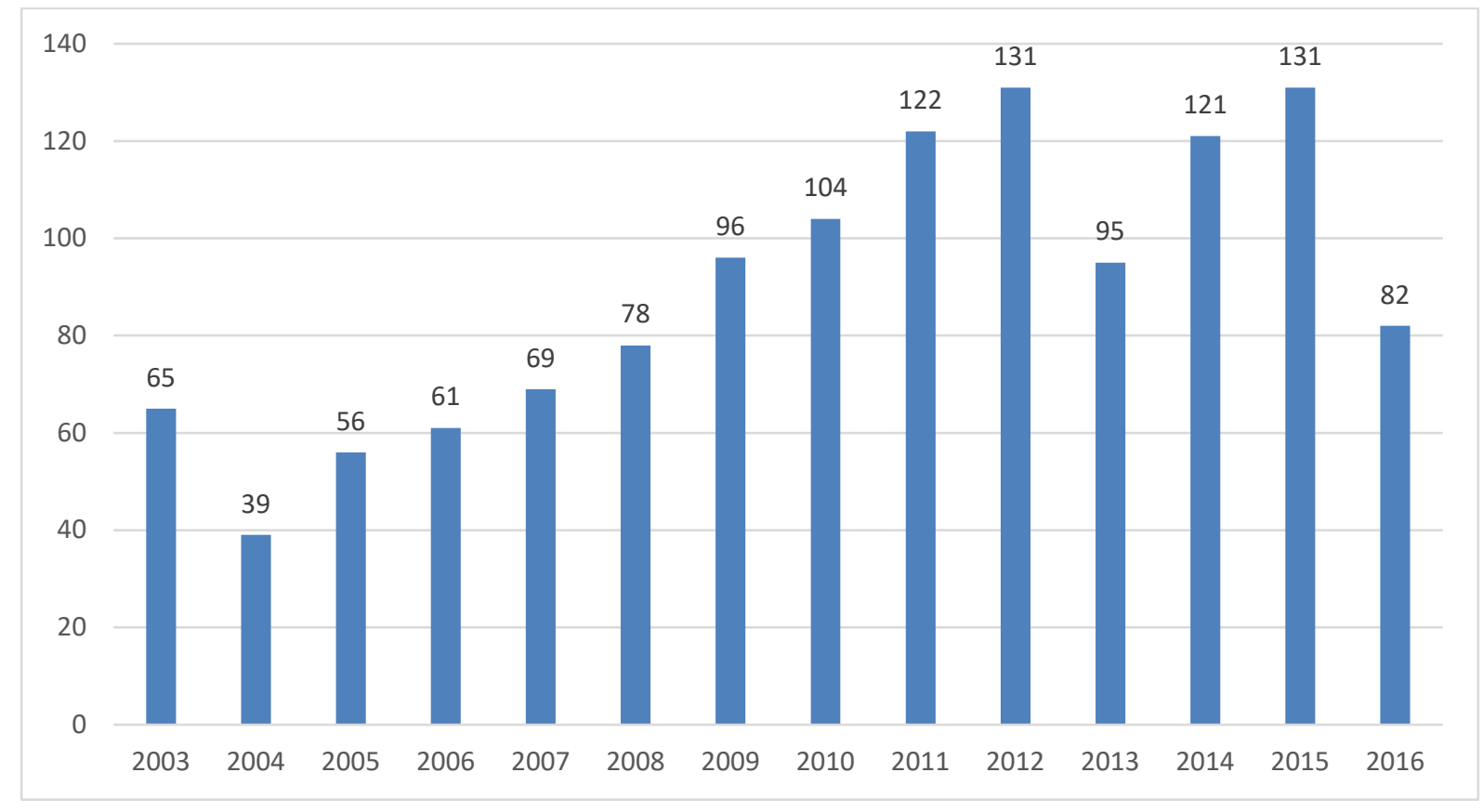

Figure 1: The number of scientific articles about innovation adoption per year included in this review

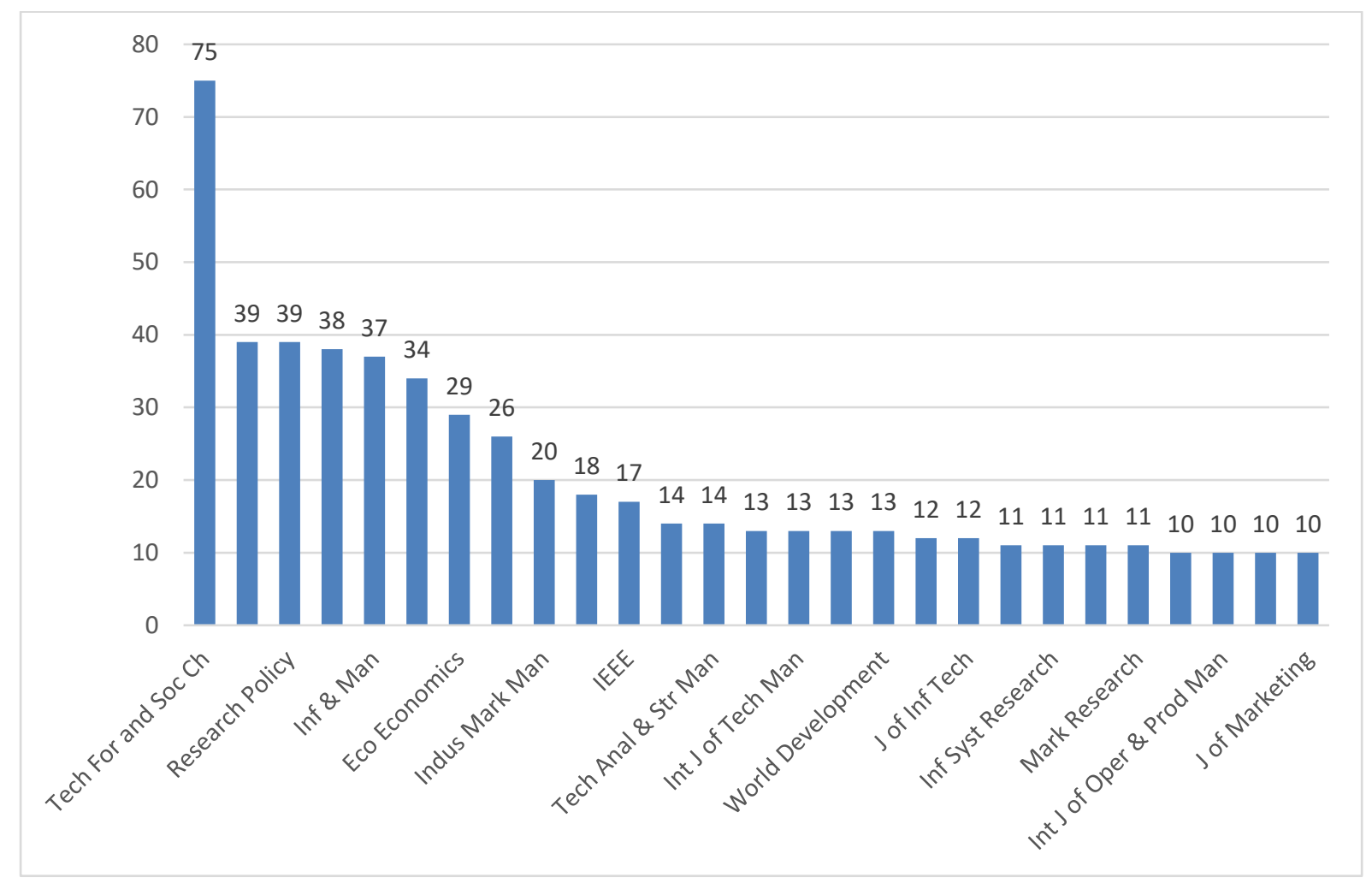

Figure 2: Number of scientific articles about innovation adoption per year per academic journal (560 articles (out of 1260), or 44\%, have been published in 27 scientific journals). 


\subsection{Methods: Bibliographic coupling and co-citation analysis}

Many methodological scholars have emphasized the need for a process of systematic reviewing in order to overcome the bias challenge facing scientific literature reviews. The principles of “systematic reviewing” are based on a replicable, scientific and transparent protocol. Such protocols minimize human error and bias in mapping and synthesizing the fragmented empirical studies [26, 27]. To further reduce the reviewer bias, it would be possible to perform a bibliometric analysis that does not depend on the reviewer's knowledge or preferences [28]. In order to identify thematic similarities between articles published in scientific journals on innovation adoption, we rely on two bibliometric analysis techniques based on the overlap between reference patterns: (1) bibliographic coupling and (2) co-citation analysis.

Bibliographic coupling clusters recent articles but fewer old articles: co-citation clustering does the opposite, being unable to cluster the most recent articles that have not yet been cited [29]. Clusters identified by co-citation analysis form the cornerstones of the research front in the literature on innovation adoption while bibliographic coupling helps to identify clusters representing the more recent research themes that do not necessarily match the cornerstones. The methods differ from each other in the direction of referencing: this is visualised in Figures 3 and 4 (adapted from Boyack and Klavans, 2010 [29]). The grey box in Figures 3 and 4 represents the longitudinal dataset of innovation adoption articles that are included in the review. Articles A, B, C, D and E represent the most recent published articles, and papers M, N, O and P are somewhat older, dating from 2003. Articles W, X, Y and Z were published before 2003 and are not part of the longitudinal dataset but, as they are cited by publications in the longitudinal dataset, they are included as external references.

Co-citation analysis allows us to reveal the theoretical foundations of the research field by assessing the similarities among cited articles [29]. Clusters A and B in Figure 3 are 
derived from the co-citation analysis and, as is evident, these clusters contain articles that are published prior to the articles included in the dataset.

Bibliographic coupling links documents that reference the same set of cited documents and is used to assess the similarity between citing articles [29]. This is illustrated in Figure 4; Clusters 1 and 2 result from bibliographic coupling of the articles in the dataset. Note that the older articles in the innovation adoption dataset, represented by articles $\mathrm{M}, \mathrm{N}, \mathrm{O}$ and P, could be included in a co-citation cluster as well as a cluster identified by bibliographic coupling.

Following Kovacs et al. [14], we combine these complementary techniques to uncover both past research traditions and current trends in the field of innovation adoption. For a more detailed description of this approach, see Boyack and Klavans [29] and Kovacs et al. [14]. In line with the work of Van Eck and Waltman [13], this review applies their association strength measure to reveal the clustering of innovation adoption articles, i.e. it determines the normalized strength between related papers based on similarities among their reference lists (p531):

$$
S_{i j}=\frac{C_{i j}}{W_{i} W_{j}}
$$

$C_{i j}=$ Number of citations (received by) or references (referred to) that articles $i$ and $j$ have in common; $W_{i}=$ Total number of citations or references article $i ; W_{j}=$ Total number of citations or references article $j$.

The relative distance (the higher the values of $S_{i j}$ ) between the focal articles $A$ and $B$ based on the reference list depends on the quotient between overlapping references and the number of references that could have been made by both publications. This calculation is made for every pair of publications included in the review, one time based on bibliographic coupling and the other time based on co-citation. We used the Visualization of Similarities (VOS) approach (http://www.vosviewer.com) to identify and visualize thematic clusters based on the 
relatedness between our set of publications [13]. VOS software combines optimization and clustering algorithms to visualize the relative distance, which reflect the level of similarity between reference lists, and between articles included in the analysis. For the mathematical details, we refer to Van Eck and Waltman [13]. The software places the most connected articles in the middle of the two-dimensional space and, thus, the least connected articles are printed at relative distance from the centre. Next, articles are presented in clusters based on Newman and Givan's modularity function [30], where the maximization of the modularity function is parameterized by a resolution parameter. In the VOS Viewer, this parameter can be adjusted to alter the (optimal) number of clusters derived. This parameter is particularly useful in identifying small clusters - a weakness of modularity-based clustering techniques. In our study we slightly adjusted the resolution parameter, set at 0.75 in contrast to the default setting of 1.0, which resulted in a clearer distinction between cluster, all other settings were set to default. In figure 5 the size of the title of individual publications and the size of the corresponding circle indicate the importance of the publication within the map, depending on the number of neighbouring articles, the distance between these articles and the number of citations these articles received. The distance between two articles explains the overlap between them, i.e. the closer two articles are positioned to each other the more the overlap between the work cited by these publications. Items positioned at a larger distance are less often cited together. Based on the proximity between all publications, clusters are formed which are highlighted with different colours in the map. As explained earlier, to facilitate interpretation of each cluster we also gave a unique label to each cluster that best matches the content of each cluster of publications. Clusters located next to each other indicate closely related fields. Visa versa, clusters at a relative distance cover more different research fields [13]. 


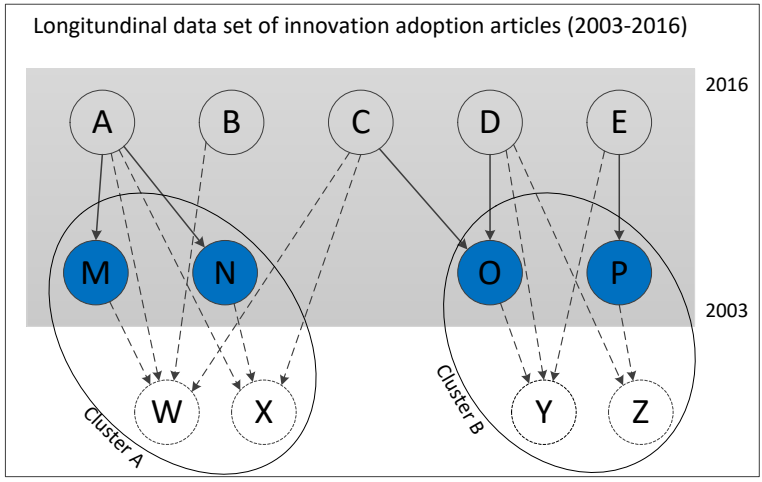

Figure 3: Illustration of co-citation analysis (adapted from Boyack and Klavans, 2010 [29]). The grey box represents the longitudinal dataset of innovation adoption papers included in the review. Articles A-E represent the most recent published articles and papers. M-P are somewhat older going back to 2003. Articles W-Z were published before 2003 and were not included in the review. Clusters $\mathrm{A}$ and $\mathrm{B}$ result from the formation of co-cited articles and, thus, these clusters contain articles that were published before the articles in the dataset. Clusters A and B are referred to as the theoretical cornerstones of innovation adoption research.

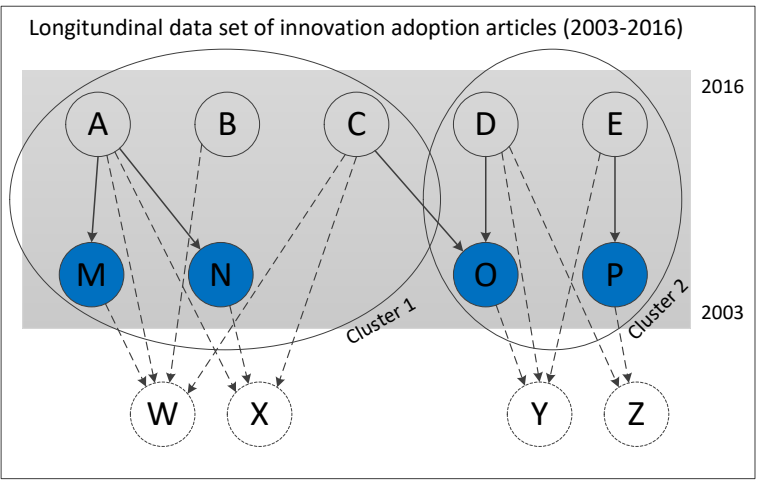

Figure 4: Illustration of bibliographic coupling (adapted from Boyack and Klavans, 2010 [29]). The grey box represents the longitudinal dataset of innovation adoption papers included in the review. Articles A, B, C, D and E represent the most recent published articles, and papers $\mathrm{M}, \mathrm{N}, \mathrm{O}$ and $\mathrm{P}$ are somewhat older, going back to 2003. Articles W-Z were published before 2003 and were not included in the review. Clusters 1 and 2 result from bibliographic coupling of the articles in the dataset based on the links between the articles that reference the same set of cited articles.

\section{CORNERSTONES OF INNOVATION ADOPTION RESEARCH}

Figure 5 shows the bibliographic network based on co-citation analysis and reveals the theoretical cornerstones of innovation adoption research. Figure 5 displays a relatively coherent network in which clusters A, B, C and D are tied together by different editions of Rogers' seminal work positioned in the core of the network [2, 3, 31, 32]. We included externally cited references in the analysis [29]. Taking into account the different citation styles of journals, this resulted in the identification of 45,932 unique references. To facilitate interpretation of the clusters, we restricted our focus to references that were cited 20 times or more. This helped us to focus on the most important publications and facilitated interpretation of the identified clusters in the network. Our network of publications, shown in Figure 5, consists of four clusters. Each cluster consists of vertices that represent the cited references. Publications represented by larger vertices are cited more often by the publications in our longitudinal dataset than those that are represented by smaller vertices. The distance between 
vertices corresponds to the likelihood of co-citation, i.e. the closer two vertices are located together in the network, the more likely these references will be cited together. In this respect, publications in a cluster are more likely to be cited together than any combination of publications from separate clusters.

It should be noted that the four clusters are tied together by four (out of five) editions of Everett Rogers' Diffusion of Innovations [2, 3, 31, 32]. As the latest version of Rogers' book, Diffusion of Innovations [3], has been used for the development of the search query “innovation adoption”, it will not be considered in detail in order to derive a meaningful and distinctive description of each cluster. For the same reason, methodological publications are not considered any further. The relatively empty centre of the structure indicates that clusters are clearly separated from each other (Van Eck and Waltman, 2010, p.535). A more detailed analysis in Figure 5 indicates that Clusters C and D are relatively coherent where "gaps" or relative empty spaces can be found between publications in Clusters A and B. Following the protocol discussed in Section 2.1, the following clusters have been identified: A) Institutional Theory and the legitimization of innovative behaviour; B) Theory of Reasoned Action and the Technology Acceptance Model; C) The determinants of innovation adoption, an econometric perspective; and D) Diffusion Theory. In the following sections, 3.1 to 3.4, we assess the theoretical cornerstones of innovation adoption research, i.e. we define each of the four identified clusters and assess the relative importance of the clusters. 


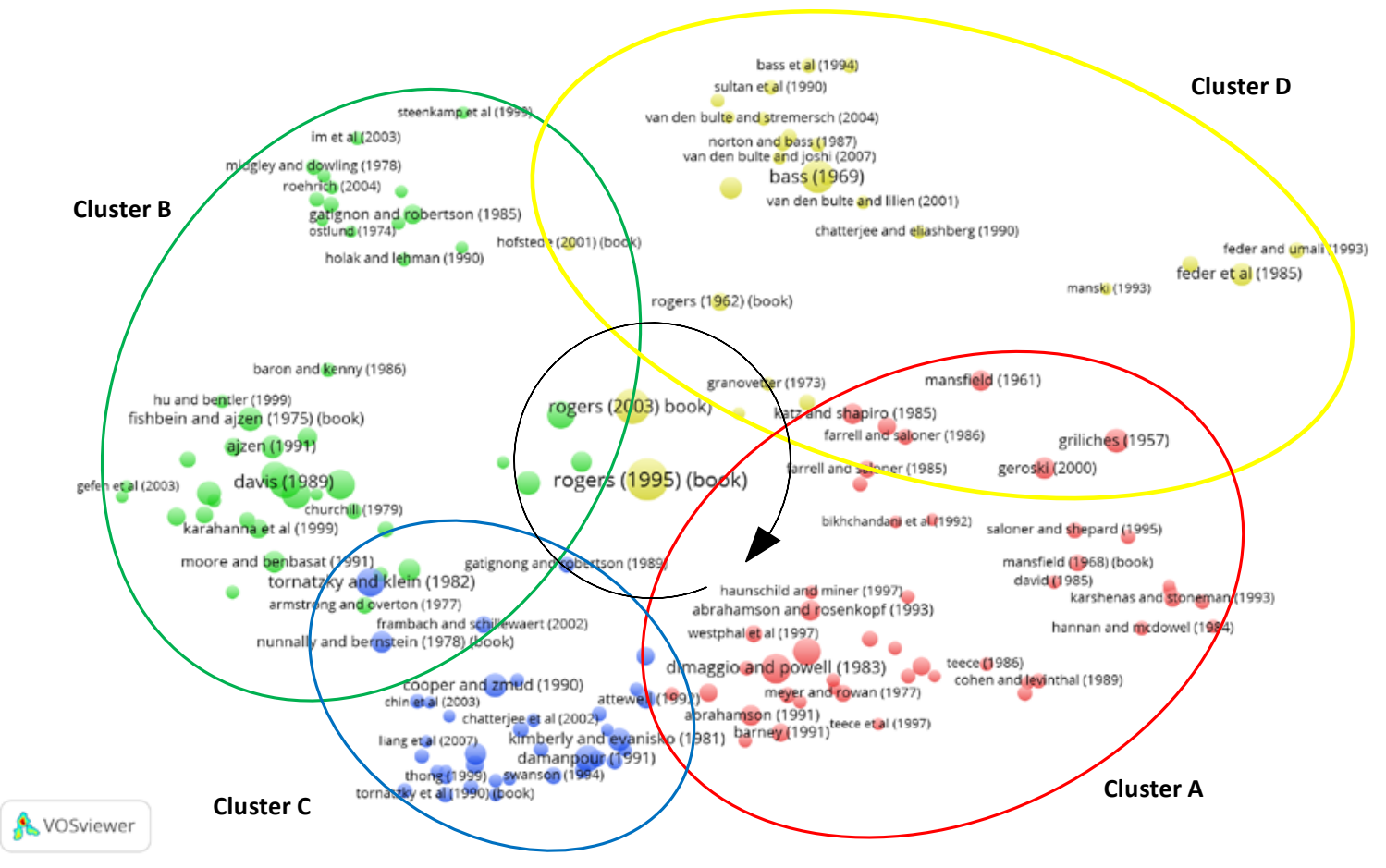

Figure 5: Co-citation network of references cited by innovation adoption publications between 2003 and 2016. The research fields, or theoretical cornerstones, are linked to each other by the seminal work of Rogers on which we base our search query.

\subsection{Cluster A: Institutional Theory and the legitimization of innovative behaviour}

Cluster A, which includes 37 articles and 7 book publications, can be labelled as "Institutional Theory and the legitimization of innovative behaviour". In common, the publications in this cluster address forces that dictate how firms behave, how they innovate and which innovations they adopt. One of the most important explanations can be found in Institutional Theory. Next, four themes related to firm behaviour with respect to innovation and innovation adoption and diffusion were identified in the periphery of Cluster A. Finally, three methodological publications were dropped while they do not address innovation adoption or diffusion. Table 3 provides an overview of the 44 publications, their theoretical contribution and the implications for innovation adoption-diffusion research. Table 3 makes 
clear that most of the publications included in Cluster A address firm behaviour at the aggregate level and do not address innovation adoption in particular. Moreover, the few publications which address adoption and/or diffusion are found in the periphery of Cluster A. Therefore, we have organized the publications according to the theoretical concept upon which they build and have deduced the conceptual adoption mechanism from them as shown in the last column. To grasp this cluster, we drew on the work of Agrote and Greve [33].

In the main, Cluster A encompasses the theoretical background from which scholars derived their conceptualizations in order to explain innovative behaviour and, thus, innovation adoption (as is evident in Section 4). In this respect, Cluster A is considered better "grounded in theory" than the clusters discussed in the next sections. In particular, institutional theory is well covered (table 3). Conceptualizations based on institutional theory build upon the notion that the acceptance of any innovation, or any other form of change challenging an incumbent institution, depends, by and large, on its (regulative, normative and cultural-cognitive) legitimacy. In this regard, it opposes the socio-economic efficiency considerations addressed in Cluster C [34].

Four themes related to firm innovative behaviour can be found in the periphery of Cluster A. Closely related to Cluster D, the first theme addresses adoption-diffusion from an econometric viewpoint. Before the well-known work of Rogers [2] and Bass [35], Griliches [36] and Mansfield [37, 38] published about "the longer-run aspects [in the economics] of technology change" (Griliches, 1957, p521) and "technological change and the differences among innovations in the rate of imitation” (Mansfield 1961, p741). The work of Griliches (1957) presents a logistic growth function (S-curve) based on parameter origins (availability of a new technique), slopes (rate of acceptance) and ceilings (equilibrium level use). Mansfield [37] introduced an imitation model based on the hypothesis that: "the probability that a firm will introduce a new technique is an increasing function of firms already using it 
and the profitability of doing so, but a decreasing function of the size of the investment require” (pp.762-763) ${ }^{2}$. The publication of Geroski (2000) studied several alternative technology diffusion models [22]. In contrast to the dominant S-curve diffusion model or epidemic model, two alternative approaches are emphasized (probit models and models of density dependence).

Next, the second theme embodies the Network Externalities Theory, which studies the implications of network effects on innovation adoption-diffusion [39-41]. "Direct network externalities" refers to the notion that the level of user value depends on the size of the installed base, i.e. the number of other adopters of the innovation. In contrast, indirect network externalities increase utility through the availability of complementarities; for example, the availability of DVDs (complementarities) increases the utility of DVD players (installed base).

A third topic addresses the relation between complementary organizational capabilities and innovation [42]. In this respect, Cohen and Levinthal [43, 44] introduced the concept of Absorptive Capacity. Moreover, Teece et al. [45] introduced the concept of Dynamic Capabilities. Dynamic Capabilities encompass specific capabilities and resources which constitute a firms’ competitive advantage. This framework has been applied by scholars to assess how a set of competences and resources are developed, deployed, and protected by a specific firm within changing and competitive economic environments. In contrast to research projects that study the adoption of innovation in isolation, Bresnahan et al. [46] analysed the effect of the complementary adoption of three related innovations.

Finally, the publications which do assess the adoption and diffusion of innovation are found in the periphery of Cluster A. Jensen [47] and Karshenas and Stoneman [48] for example attempted to bridge the gap between the work of Griliches and Mansfield and the

\footnotetext{
${ }^{2}$ Rogers made the terms "adoption" and "diffusion" popular among scholars. However, the early work in this field dates back to Gabriel [de] Tarde who introduced the "Laws of Imitation" around 1900 and, therefore, these terms are used in early publications.
} 
work of Rogers by addressing the gap between understanding adoption-diffusion behaviour at

the aggregate industry level and individual firm's adoption behaviour taking into account

both economic and information communication factors. Thus, these publications take into

account market structure and organizational innovation behaviour [49-53].

Table 3: Overview of the 44 publications in Cluster A. The publications included address, how firms innovate, and which innovations they adopt from a behavioural point of view.

\begin{tabular}{|c|c|c|}
\hline Reference: & Theory: & Conceptual adoption mechanisms deduced from theory*: \\
\hline Cyert and March, 1963 [54] & $\begin{array}{l}\text { Behavioural Theory of } \\
\text { the Firm }\end{array}$ & $\begin{array}{l}\text { Adoption behaviour (the adoption of innovation) depends on } \\
\text { several mechanisms which related to: bounded rationality of } \\
\text { the firm; firm"s problematic search; the dominant coalition; } \\
\text { standard operating procedures within the firm, and firms } \\
\text { slack search - subsequently, these mechanisms can be found } \\
\text { in a number of related organizational theories. }\end{array}$ \\
\hline $\begin{array}{l}\text { Nelson and Winter, } 1982 \\
\text { [55]; Tushman and } \\
\text { Anderson, } 1986 \text { [56] }\end{array}$ & $\begin{array}{l}\text { Evolutionary Economic } \\
\text { Theory }\end{array}$ & $\begin{array}{l}\text { Longitudinal perspective on technological change; } \\
\text { technologies evolve through periods of incremental change } \\
\text { punctuated by breakthroughs that affect firm (adoption) } \\
\text { behaviour (prompted by uncertainty). }\end{array}$ \\
\hline $\begin{array}{l}\text { Meyer and Rowan, } 1977 \\
\text { [57]; Tolbert and Zucker, } \\
\text { 1983 [58]; DiMaggio and } \\
\text { Powell, 1983 [59]; } \\
\text { Abrahamson, 1991 [34]; } \\
\text { Bikhchandani et al., 1992 } \\
\text { [60]; Abrahamson and } \\
\text { Rosenkopf, 1993; 1997 [61, } \\
\text { 62]; Suchman, 1995 [63]; } \\
\text { Westphal, Gulati and } \\
\text { Shortell, 1997 [64]; } \\
\text { Haunschild and Miner, } \\
\text { 1997 [65]; Abrahamson and } \\
\text { Fairchild, 1999 [66]; }\end{array}$ & Institutional Theory & $\begin{array}{l}\text { The acceptance of any innovation, or any other form of } \\
\text { change challenging an incumbent institution, mainly depends } \\
\text { on its (regulative, normative and cultural-cognitive) } \\
\text { legitimacy (in contrast to economic efficiency } \\
\text { considerations). }\end{array}$ \\
\hline $\begin{array}{l}\text { Cohen and Levinthal, 1989; } \\
1990 \text { [43, 44]; Milgrom and } \\
\text { Roberts, 1990 [42]; Teece, } \\
1986 \text { [67]; Teece et al., } \\
1997 \text { [45]; Bresnahan et al.,, } \\
2002 \text { [46] }\end{array}$ & $\begin{array}{l}\text { Absorptive Capacity, } \\
\text { dynamic capabilities and } \\
\text { complementarities }\end{array}$ & $\begin{array}{l}\text { The ability of a firm to recognize the value of new, external } \\
\text { information; the ability to assimilate this information; and } \\
\text { the capability to apply this information during adoption } \\
\text { (decision making). In addition, often complementary } \\
\text { organizational capabilities are required to adopt innovation. }\end{array}$ \\
\hline $\begin{array}{l}\text { Schumpeter, 1934; } 1942 \\
\text { [68, 69]; Porter, } 1980[70] ; \\
\text { Henderson and Clark, } 1990 \\
\text { [71] }\end{array}$ & $\begin{array}{l}\text { Schumpeterian } \\
\text { (economic) theory of } \\
\text { "creative destruction" }\end{array}$ & $\begin{array}{l}\text { In its essence, firms' innovative behaviour and, thus, } \\
\text { innovation adoption behaviour, is motivated by firm survival } \\
\text { considerations. }\end{array}$ \\
\hline $\begin{array}{l}\text { Barney, } 1991 \text { [72]; Pfeffer } \\
\text { and Salancik, } 1978 \text { [73] }\end{array}$ & Resource-based view & $\begin{array}{l}\text { Adoption depends on a firm's belief that the innovation is a } \\
\text { future strategic resource that must be obtained in order to } \\
\text { sustain a competitive advantage. }\end{array}$ \\
\hline $\begin{array}{l}\text { Farrell and Saloner, 1985; } \\
\text { 1986 [40, 41]; Katz and } \\
\text { Shapiro, 1985; } 1986 \text { [39, } \\
\text { 74]; Saloner and Shepard, } \\
\text { 1992 [75] }\end{array}$ & $\begin{array}{l}\text { Network externalities } \\
\text { Theory }\end{array}$ & $\begin{array}{l}\text { The adoption of innovation with network effects depends on } \\
\text { the availability of direct and indirect network externalities } \\
\text { (for example, the availability of DVDs increases the utility of } \\
\text { DVD players). }\end{array}$ \\
\hline $\begin{array}{l}\text { Griliches, } 1957 \text { [36]; } \\
\text { Mansfield, 1961; } 1969 \text { [37, } \\
\text { 38]; Geroski, 2000 [22] }\end{array}$ & Diffusion econometrics & $\begin{array}{l}\text { Modelling the longer run aspects of technology change and } \\
\text { the differences among innovation in the rate of imitation } \\
\text { (following a S-curve). }\end{array}$ \\
\hline $\begin{array}{l}\text { Reinganum, } 1981 \text { [49]; } \\
\text { Jensen, } 1982 \text { [47]; Hannan } \\
\text { and McDowell, 1984 [50]; }\end{array}$ & $\begin{array}{l}\text { Market structure and } \\
\text { organizational innovation } \\
\text { adoption behaviour }\end{array}$ & $\begin{array}{l}\text { Bridges the gap between the work of Griliches and } \\
\text { Mansfield and the work of Rogers by addressing the gap } \\
\text { between understanding adoption-diffusion behaviour at the }\end{array}$ \\
\hline
\end{tabular}


*conceptual because the mechanisms are relatively abstract compared to the mechanisms identified in Cluster 3.

\subsection{Cluster B: Theory of Reasoned Action and the Technological Acceptance Model}

Cluster B is labelled as: “Theory of Reasoned Action and the Technology Acceptance Model”. Cluster B encompasses 30 publications, including 2 book publications, that can be subdivided into two groups of closely related publications, B1 and B2 respectively. About 11 methodological publications were dropped as were three versions of Rogers’ Diffusion of Innovations book. Next, we discuss the two subsets in more detail.

The 16 articles of Subset B1 build upon the concept of technology acceptance. The Technology Acceptance Model is grounded in the Theory of Reasoned Action (TRA) developed by Fishbein and Ajzen [76] from which, later on, the "(Decomposed) Theory of Planned Behavior” ((D)TPB) has been developed [77-79]. The TRA has been developed to predict and explain social behaviour in general. The Technology Acceptance Model (TAM) was introduced by Davis [80] and was developed to specifically explain computer usage intention and actual usage behaviour. Later studies refined the original TAM [81-83], which resulted in several versions of the model such as TAM2 [83] and the Unified Theory of Acceptance and Use of Technology (UTAUT) [17]. The basic assumptions of TAM encompass the causal relation between Perceived Usefulness, Perceived Ease of Use, and the decision makers' attitudes, intentions and actual innovation usage. In general, this research stream demonstrates that the intention to use an innovation is the only accurate predictor of the actual adoption and use of the innovation [84].

How are the innovation adoption-diffusion and the innovation acceptance line of debate positioned alongside each other? Four articles in this cluster focus on complementarities between both lines of debate [85-88]. Criticizing the adoption-diffusion 
theory, these scholars claim that the adopters' perception of the innovation does not itself explain its diffusion but rather their perception of applying the innovation. This critique has been stimulated by Rogers’ definitions of the five perceived innovation characteristics (i.e. relative advantage, compatibility, complexity, observability and trialability) [3]. Addressing this critique, the innovation acceptance line of debate is based on the assumption that innovation behaviour (usage) is preceded by the intention to use the innovation. In contrast, the innovation acceptance line of debate has been criticized for its lack of a comprehensive set of attributes explaining technology acceptance outcomes as found in innovation adoptiondiffusion research. As a result, several attempts have been made to include these attributes in the TAM (see Cluster 1, Section 4.1).

Fourteen articles form a subset in Cluster B, referred to as B2, although these articles are closely related to the technology acceptance line of debate $[23,89,90]$. Their relative distance from the rest of the articles can be explained by the origins of these papers; the core publications were published just prior to the introduction of the concept of technology acceptance. The publications within subset B2 explore consumer innovativeness in more detail [89, 91]. The review of Roehrich (2004) revealed that the concept of innovativeness is still under debate and lacks clear conceptualizations and measures (even after decades of research since its introduction in the early seventies) [91].

\subsection{Cluster C: Determinants of innovation adoption, an econometric perspective}

This cluster is labelled “The determinants of innovation adoption, an econometric perspective” and includes 35 publications. Cluster C encompasses subsequently 33 scientific papers and 2 book publications. Two publications were dropped as these references o0nly include research methodology issues. Compared to Clusters A, B and D, Cluster C is relatively coherent. As can be seen in Figure 5, Cluster C is closely related to Cluster D and, 
therefore, publications assigned to Cluster $\mathrm{C}$ are more often cited in combination with publications from Cluster D in contrast to Clusters A and B. From the publications constituting Cluster $\mathrm{C}$ it was derived that these publications apply a variance based approach as the dominant research strategy. More specifically, Cluster C publications apply unidirectional causations to assess the impact of determinants on the adoption of specific innovations within various contexts (see table 4).

The articles in this cluster all address the Downs and Mohr critique [92] on the generalizability of research findings on innovation adoption. In their article, they argued that innovation adoption models lacked a rigorous theoretical foundation and were too simplistic since they failed to take into account contextual differences, i.e. contingency variables. Most of the publications in this cluster examine the contingencies influencing the adoption of different types of innovation in different contexts [93, 94].

In contrast, Tornatzky and Klein’s [20] meta-analysis addresses the question of whether "across an heterogeneous array of innovations, actors, and organizations, the innovation characteristic-adoption relationship vary widely or reverse itself' (p.29). These scholars oppose, to some degree, the argument in Downs and Mohr's critique. Instead, Tornatzky and Klein propose that "perceived innovation characteristics can predict the adoption and implementation of various innovations, and with some degree of consistence across various settings. [They] assume that the literature fails, to a considerable extent, to exploit this possibility because of methodological and conceptual problems in many of the innovation characteristic studies”(p.29). Meyer and Goes [95] and Cooper and Zmud [96] also presented several methodological and conceptual shortcomings regarding adoption research.

Furthermore, Damanpour [18] has levelled the criticism that researchers have overemphasized sub-theories of organizational innovation adoption. According to 
Damanpour, the purpose of those studies, such as Kimberly and Evanisko [93] and Dewar and Dutton [94], was to further explore several specific dimensions of innovation and their determinants. However, the sub-theories have not been evaluated in different contexts (p.556). In contrast, several researchers claim that an unified adoption theory does not exist at all because the variations in innovations and the adoption context in which the innovations will be applied are unique, and that the contingencies of every situation must be taken into account $[97,98]$. A recent meta-analysis conducted by Jeyaraj et al. (2006) shed some new light on this debate [99]). These authors assessed the determinants which affect IT adoption at the individual and organizational level. They found that, at the aggregate level, innovation and organizational determinants are both predictors of individual and organizational adoption. These scholars conclude that both categories of determinants are strong predictors of IT adoption at the individual and organizational level.

Taken together, this cluster addresses the different conceptualizations of the adoption of distinct innovations affected by a specific set of contingency variables. The two most frequently applied frameworks to study innovation adoption in its context, including innovation, organizational and contextual determinants, have been developed by Tornatzky and Fleisher (1990) and Iacovou et al. (1995) [100, 101]. Moreover, Cluster C can be considered as the birthplace of middle-range theories of adoption. 
Table 4: Determinants of innovation adoption; an econometric perspective on middle-range theories of adoption

\begin{tabular}{|c|c|c|c|c|}
\hline Reference & Determinants affecting adoption & Innovation & Framework & Cross reference within Cluster C \\
\hline $\begin{array}{l}\text { Attewell, } 1992 \\
\text { [102] }\end{array}$ & Organizational learning & Business computing & $\begin{array}{l}\text { Tornatzky and Fleisher's } \\
\text { Technology-Organization- } \\
\text { Environment framework }\end{array}$ & $\begin{array}{l}\text { Kimberley and Evanisko, } 1981 \text { [93]; Rogers, } 1983 \\
\text { [31]; Tornatzky and Fleisher, } 1990 \text { [100] }\end{array}$ \\
\hline $\begin{array}{l}\text { Chatterjee et al., } \\
2002 \text { [103] }\end{array}$ & $\begin{array}{l}\text { Top Management Support, strategic investment rationale, extent of } \\
\text { coordination }\end{array}$ & Web technologies & & $\begin{array}{l}\text { Tornatzky and Klein, } 1982 \text { [20]; Rogers, } 1983 \text { [31]; } \\
\text { Meyer and Goes, } 1988 \text { [95]; Cooper and Zmud, } \\
1990 \text { [96]; Fichman and Kemerer, } 1999 \text { [104] }\end{array}$ \\
\hline $\begin{array}{l}\text { Chau and Tam, } \\
1997[105]\end{array}$ & $\begin{array}{l}\text { Firms tend to focus more on their "ability to adopt" than on the } \\
\text { "benefits from adoption"; firms take a reactive rather than } \\
\text { "proactive" attitude in adopting open systems technology }\end{array}$ & Open systems & $\begin{array}{l}\text { Tornatzky and Fleisher's } \\
\text { Technology-Organization- } \\
\text { Environment framework }\end{array}$ & $\begin{array}{l}\text { Zaltman et al., } 1973 \text { [106]; Downs and Mohr, } \\
\text { 1976 [92]; Rogers, } 1983 \text { [31]; Tornatzky and } \\
\text { Fleisher, } 1990 \text { [100]; Attewel, } 1992 \text { [102] } \\
\end{array}$ \\
\hline $\begin{array}{l}\text { Chwelos et al., } 2001 \\
\text { [107] }\end{array}$ & Readiness, perceived benefits, external pressure & $\begin{array}{l}\text { Electronic data } \\
\text { interchange (EDI) }\end{array}$ & $\begin{array}{l}\text { Iacovou, Benbasat and } \\
\text { Dexter framework }\end{array}$ & $\begin{array}{l}\text { Tornatzky and Klein, } 1982 \text { [20]; Damanpour, } 1992 \\
\text { [108]; Premkumar et al., 1994 [109]; Premkumar } \\
\text { and Ramamurthy, } 1995 \text { [110]; Iacovou et al., } 1995 \\
\text { [101]; Rogers, } 1995 \text { [32] }\end{array}$ \\
\hline $\begin{array}{l}\text { Cooper and Zmud, } \\
1990 \text { [96] }\end{array}$ & Compatibility, Technology complexity & $\begin{array}{l}\text { Material } \\
\text { requirements } \\
\text { planning: MRP (IT) }\end{array}$ & & $\begin{array}{l}\text { Downs and Mohr, } 1976 \text { [92]; Tornatzky and } \\
\text { Klein, } 1982 \text { [20]; Rogers, } 1983 \text { [31] }\end{array}$ \\
\hline $\begin{array}{l}\text { Damanpour, } 1991 \\
{[18]}\end{array}$ & $\begin{array}{l}\text { Organizational determinants: specialization, functional } \\
\text { differentiation, professionalism, centralization, managerial attitude } \\
\text { toward change, technical knowledge resources, administrative } \\
\text { intensity, slack resources, and external and internal communication }\end{array}$ & Meta-analysis & Meta-analyses & $\begin{array}{l}\text { Zaltman et al., } 1973 \text { [106]; Downs and Mohr, } \\
\text { 1976 [92]; Dewar and Dutton, } 1986 \text { [94]; Kimberly } \\
\text { and Evanisko, } 1981 \text { [93]; Tornatzky and Klein, } \\
1982 \text { [20]; Meyer and Goes, } 1988 \text { [95] }\end{array}$ \\
\hline $\begin{array}{l}\text { Damanpour, } 1992 \\
{[108]}\end{array}$ & Organizational size & & & \\
\hline $\begin{array}{l}\text { Damanpour and } \\
\text { Schneider, } 2006 \\
{[111]}\end{array}$ & Environmental, organizational and top managers' characteristics & $\begin{array}{l}\text { Administrative } \\
\text { programmes }\end{array}$ & $\begin{array}{l}\text { Tornatzky and Fleisher’s } \\
\text { Technology-Organization- } \\
\text { Environment framework }\end{array}$ & $\begin{array}{l}\text { Zaltman et al., } 1973 \text { [106]; Dewar and Dutton, } \\
1986 \text { [94]; Kimberly and Evanisko, } 1981 \text { [93]; } \\
\text { Meyer and Goes, } 1988 \text { [95]; Tornatzky and } \\
\text { Fleisher, } 1990 \text { [100]; Damanpour, 1991; } 1992 \text { [18, } \\
\text { 108]; Rogers, 1995 [32]; Hofstede, } 2001 \text { [112]; } \\
\text { Wejnert, } 2002 \text { [113] }\end{array}$ \\
\hline $\begin{array}{l}\text { Dewar and Dutton, } \\
1986 \text { [94] }\end{array}$ & $\begin{array}{l}\text { (Levels of) knowledge [no effect of decentralized } \\
\text { decision making, managerial attitudes toward change, and } \\
\text { exposure to external information] }\end{array}$ & $\begin{array}{l}\text { Technical process } \\
\text { innovation }\end{array}$ & & $\begin{array}{l}\text { Zaltman et al., } 1973 \text { [106]; Downs and Mohr, } \\
1976 \text { [92]; Kimberley and Evanisko, } 1981 \text { [93] }\end{array}$ \\
\hline $\begin{array}{l}\text { Fichman and } \\
\text { Kemerer, } 1997 \\
\text { [114] }\end{array}$ & $\begin{array}{l}\text { Organizational learning [knowledge barriers]: learning costs; } \\
\text { related knowledge, knowledge diversity }\end{array}$ & $\begin{array}{l}\text { Software process } \\
\text { innovation }\end{array}$ & $\begin{array}{l}\text { Tornatzky and Fleisher’s } \\
\text { Technology-Organization- } \\
\text { Environment framework }\end{array}$ & $\begin{array}{l}\text { Downs and Mohr, } 1976 \text { [92]; Rogers, } 1983 \text { [31]; } \\
\text { Tornatzky and Fleisher, } 1990 \text { [100]; Damanpour, } \\
1991 \text { [18]; Attewell, } 1992 \text { [102] }\end{array}$ \\
\hline $\begin{array}{l}\text { Fichman and } \\
\text { Kemerer, } 1999 \\
\text { [104] }\end{array}$ & Knowledge barriers, increasing returns to adoption & $\begin{array}{l}\text { Software process } \\
\text { innovation }\end{array}$ & $\begin{array}{l}\text { Tornatzky and Fleisher’s } \\
\text { Technology-Organization- } \\
\text { Environment framework }\end{array}$ & $\begin{array}{l}\text { Cooper and Zmud, } 1990 \text { [96]; Tornatzky and } \\
\text { Fleisher, } 1990 \text { [100]; Attewel, } 1992 \text { [102]; Rogers, } \\
1995 \text { [32]; Fichman and Kemerer, } 1997 \text { [114] }\end{array}$ \\
\hline
\end{tabular}




\begin{tabular}{|c|c|c|c|c|}
\hline $\begin{array}{l}\text { Frambach and } \\
\text { Schillewaert, } 2002 \\
\text { [25] }\end{array}$ & $\begin{array}{l}\text { Innovation, organizational and individual (within firm context) } \\
\text { determinants }\end{array}$ & Model development & & $\begin{array}{l}\text { Zaltman et al., } 1973 \text { [106]; Kimberly and Evanisko, } \\
1981 \text { [93]; Tornatzky and Klein, 1982 [20]; } \\
\text { Gatignon and Robertson, } 1989 \text { [115]; Damanpour, } \\
1991 \text { [18]; Rogers, } 1995 \text { [32] }\end{array}$ \\
\hline $\begin{array}{l}\text { Gatignon and } \\
\text { Robertson, } 1989 \\
\text { [115] }\end{array}$ & $\begin{array}{l}\text { Effect of competition on adoption behaviour as well as the effect } \\
\text { of organization/taks characteristics and DMU information- } \\
\text { processing characteristics (all including several determinants) }\end{array}$ & $\begin{array}{l}\text { High-tech } \\
\text { innovation }\end{array}$ & & $\begin{array}{l}\text { Zaltman et al., } 1973 \text { [106]; Kimberly and Evanisko, } \\
1981 \text { [93]; Rogers, } 1983 \text { [31]; }\end{array}$ \\
\hline $\begin{array}{l}\text { Grandon and } \\
\text { Pearson, 2004 [116] }\end{array}$ & $\begin{array}{l}\text { Perception strategic value: operational support, managerial } \\
\text { productivity, and strategic; decision aids; From TAM: } \\
\text { organizational readiness, external pressure, perceived ease of use, } \\
\text { and perceived usefulness }\end{array}$ & E-commerce & $\begin{array}{l}\text { Iacovou, Benbasat and } \\
\text { Dexter framework }\end{array}$ & $\begin{array}{l}\text { Iacovou et al., } 1995 \text { [101]; Premkumar and Roberts, } \\
1999 \text { [117] }\end{array}$ \\
\hline Grover, 1993 [118] & $\begin{array}{l}\text { Organizational, policy, environmental, support and innovation (IT) } \\
\text { factors }\end{array}$ & $\begin{array}{l}\text { Customer based } \\
\text { inter-organizational } \\
\text { systems (IT) }\end{array}$ & & $\begin{array}{l}\text { Zaltman et al., } 1973 \text { [106]; Kimberly and Evanisko, } \\
1981 \text { [93]; Tornatzky and Klein, } 1982 \text { [20]; Rogers, } \\
1983 \text { [31]; Dewar and Dutton, } 1986 \text { [94]; Cooper } \\
\text { and Zmud, } 1990 \text { [96] }\end{array}$ \\
\hline $\begin{array}{l}\text { Iacovou et al., } 1995 \\
\text { [101] }\end{array}$ & $\begin{array}{l}\text { organizational readiness (because of the low levels of IT } \\
\text { sophistication and resource availability of small firms), external } \\
\text { pressures to adopt( because of the weak market positions of small } \\
\text { firms and the network nature of the technology), and perceived } \\
\text { benefits (because of the limited impact that IT has on small firms } \\
\text { due to under-utilization and lack of integration }\end{array}$ & EDI & $\begin{array}{l}\text { Iacovou, Benbasat and } \\
\text { Dexter framework }\end{array}$ & Rogers, 1983 [31] \\
\hline $\begin{array}{l}\text { Jeyara et al., } 2006 \\
\text { [99] }\end{array}$ & $\begin{array}{l}\text { Predictors of individual IT adoption: Perceived Usefulness, Top } \\
\text { Management Support, Computer Experience, Behavioral Intention, } \\
\text { and User Support. Predictors of IT adoption by organizations: Top } \\
\text { Management Support, External Pressure, Professionalism of the IS } \\
\text { Unit, and External Information Sources. Independent variables: } \\
\text { Top Management Support stands as the main linkage between } \\
\text { individual and organizational IT adoption; At an aggregate level, } \\
\text { two collections of independent variables were good predictors of } \\
\text { both individual and organizational IT adoption: innovation } \\
\text { characteristics and organizational characteristics. Thus, generic } \\
\text { characteristics of the innovation and characteristics of the } \\
\text { organization are strong predictors of IT adoption by both } \\
\text { individuals and organizations. }\end{array}$ & Meta-analysis & Meta-analyses & $\begin{array}{l}\text { Grover, } 1993 \text { [118]; Swanson, } 1994 \text { [119]; Iacovou } \\
\text { et al., } 1995 \text { [101]; Fichman and Kemerer, } 1999 \\
\text { [104] }\end{array}$ \\
\hline $\begin{array}{l}\text { Kimberley and } \\
\text { Evanisko, } 1981 \text { [93] }\end{array}$ & $\begin{array}{l}\text { Individual, organizational, and contextual variables were found to } \\
\text { be much better predictors of hospital adoption of technological } \\
\text { innovations than of administrative innovations. The two different } \\
\text { types of innovation were found to be influenced by different } \\
\text { variables. Organizational level variables, size in particular, were } \\
\text { clearly the best predictors of both types of innovation }\end{array}$ & $\begin{array}{l}\text { Technological } \\
\text { versus } \\
\text { administrative } \\
\text { innovation (by } \\
\text { hospital) }\end{array}$ & & $\begin{array}{l}\text { Zaltman et al., } 1973 \text { [106]; Downs and Mohr, } \\
1976 \text { [92] }\end{array}$ \\
\hline $\begin{array}{l}\text { Kuan and Chau, } \\
2001[120]\end{array}$ & $\begin{array}{l}\text { Perception-based model using TOE framework (including } \\
\text { Technology, Organizational and Environmental determinants) is a } \\
\text { useful approach for examining factors affecting adoption }\end{array}$ & $\begin{array}{l}\text { Electronic data } \\
\text { interchange (EDI) }\end{array}$ & $\begin{array}{l}\text { Tornatzky and Fleisher's } \\
\text { Technology-Organization- } \\
\text { Environment framework }\end{array}$ & $\begin{array}{l}\text { Downs and Mohr, } 1976 \text { [92]; Tornatzky and } \\
\text { Klein, } 1982 \text { [20]; Rogers, } 1983 \text { [31]; Tornatzky and } \\
\text { Fleisher, } 1990 \text { [100]; Iacovou et al., 1995 [101]; }\end{array}$ \\
\hline
\end{tabular}




\begin{tabular}{|c|c|c|c|c|}
\hline & & & & $\begin{array}{l}\text { Premkumar et al., } 1994 \text { [109]; Premkumar and } \\
\text { Ramamurthy, } 1995 \text { [110] }\end{array}$ \\
\hline $\begin{array}{l}\text { Liang et al., } 2007 \\
\text { [121] }\end{array}$ & $\begin{array}{l}\text { Importance of top management in mediating the effect of } \\
\text { institutional pressures on IT assimilation: Mimetic pressures } \\
\text { positively affect top management beliefs, which positively affects } \\
\text { top management participation in the post-adoption process and } \\
\text { continued usage. Next, coercive pressures positively affect top } \\
\text { management participation (without the mediation of top } \\
\text { management beliefs). No support for the hypothesis that top } \\
\text { management participation mediates the effect of normative } \\
\text { pressures on usage, in contrast normative pressures directly affect } \\
\text { usage. }\end{array}$ & $\begin{array}{l}\text { Enterprise resource } \\
\text { planning (ERP) }\end{array}$ & $\begin{array}{l}\text { Iacovou, Benbasat and } \\
\text { Dexter framework }\end{array}$ & $\begin{array}{l}\text { Rogers, } 1983 \text { [31]; Damanpour, 1991 [18]; Iacovou } \\
\text { et al., 1995 [101]; Chatterjee et al., } 2002 \text { [103]; Teo } \\
\text { et al., } 2003 \text { [122]; Swanson and Ramiller, 2004 } \\
\text { [119] }\end{array}$ \\
\hline $\begin{array}{l}\text { Meyer and Goes, } \\
1988 \text { [95] }\end{array}$ & $\begin{array}{l}\text { Contextual attributes, innovation attributes, and attributes arising } \\
\text { from the interaction of contexts and innovations }\end{array}$ & $\begin{array}{l}\text { Technological } \\
\text { innovations }\end{array}$ & & $\begin{array}{l}\text { Zaltman et al., } 1973 \text { [106]; Downs and Mohr, } \\
\text { 1976 [92]; Kimberly and Evanisko, } 1981 \text { [93]; } \\
\text { Tornatzky and Klein, } 1982 \text { [20]; Rogers, } 1983 \text { [31]; } \\
\text { Dewar and Dutton, } 1986 \text { [94] }\end{array}$ \\
\hline $\begin{array}{l}\text { Premkumar et al., } \\
1994 \text { [109] }\end{array}$ & $\begin{array}{l}\text { The results of the multivariate regression analyses revealed that } \\
\text { relative advantage, costs, and technical compatibility were the } \\
\text { major predictors of adaptation. While relative advantage and } \\
\text { duration were important predictors of intemal diffusion, technical } \\
\text { compatibility and duration were found to be important predictors } \\
\text { of extemal diffusion. Both forms of compatibility (technical and } \\
\text { organizational) and costs were found to be important predictors of } \\
\text { implementation success. }\end{array}$ & $\begin{array}{l}\text { Electronic Data } \\
\text { Interchange }\end{array}$ & & $\begin{array}{l}\text { Zaltman et al., } 1973 \text { [106]; Kimberly and Evanisko, } \\
1981 \text { [93]; Tornatzky and Klein, } 1982 \text { [20]; Rogers, } \\
1983 \text { [31]; Gatignon and Robertson, } 1989 \text { [115]; } \\
\text { Cooper and Zmud, } 1990 \text { [96]; Damanpour, } 1991 \\
\text { [18] }\end{array}$ \\
\hline $\begin{array}{l}\text { Premkumar and } \\
\text { Roberts, } 1999 \text { [117] }\end{array}$ & $\begin{array}{l}\text { Innovation, organizational and environmental characteristics: } \\
\text { relative advantage, top management support, organizational size, } \\
\text { external pressure and competitive pressure }\end{array}$ & $\begin{array}{l}\text { Communication } \\
\text { technology }\end{array}$ & & $\begin{array}{l}\text { Gatignon and Robertson, } 1989 \text { [115]; Cooper and } \\
\text { Zmud, 1990 [96]; Attewel, } 1992 \text { [102]; Grover, } \\
1993 \text { [118]; Rogers, } 1995 \text { [32]; Premkumar et al., } \\
1994 \text { [109]; Premkumar and Ramamurthy, } 1995 \\
\text { [110] }\end{array}$ \\
\hline Thong, 1999 [98] & $\begin{array}{l}\text { CEO characteristics (innovativeness, level of IS knowledge); } \\
\text { innovation characteristics (RA, compatibility, complexity); } \\
\text { organizational characteristics (business size, level of employees' } \\
\text { knowledge) }\end{array}$ & IT & $\begin{array}{l}\text { Tornatzky and Fleisher's } \\
\text { Technology-Organization- } \\
\text { Environment framework }\end{array}$ & $\begin{array}{l}\text { Zaltman et al., } 1973 \text { [106]; Downs and Mohr, } \\
\text { 1976 [92]; Kimberly and Evanisko, } 1981 \text { [93]; } \\
\text { Tornatzky and Klein, } 1982 \text { [20]; Rogers, 1983 [31]; } \\
\text { Dewar and Dutton, } 1986 \text { [94]; Tornatzky and } \\
\text { Fleisher, } 1990 \text { [100]; Attewel, } 1992 \text { [102]; Fichman } \\
\text { and Kemerer, 1993 [97] }\end{array}$ \\
\hline $\begin{array}{l}\text { Zhu and Kraemer, } \\
\text { 2005 (i.e Zhu et al., } \\
\text { 2003; 2006) [123- } \\
\text { 125] }\end{array}$ & $\begin{array}{l}\text { The model links technological, organizational, and environmental } \\
\text { factors (TOE framework): technology competence, firm size, } \\
\text { financial commitment, competitive pressure, and regulatory } \\
\text { support are important antecedents of e-business use. }\end{array}$ & E-business & $\begin{array}{l}\text { Tornatzky and Fleisher's } \\
\text { Technology-Organization- } \\
\text { Environment framework }\end{array}$ & $\begin{array}{l}\text { Tornatzky and Klein, } 1982 \text { [20]; Rogers, } 1983 \text { [31]; } \\
\text { Cooper and Zmud, } 1990 \text { [96]; Tornatzky and } \\
\text { Fleisher, 1990 [100]; Damanpour, } 1992 \text { [108]; } \\
\text { Iacovou et al., 1995 [101]; Fichman and Kemerer, } \\
\text { 1997 [114]; Teo et al., 2003 [122]; Zhu and } \\
\text { Kraemer, 2003 [123] }\end{array}$ \\
\hline
\end{tabular}




\subsection{Cluster D: Diffusion Theory}

Cluster D is labelled as "Diffusion Theory” since most references in this cluster focus on the mathematical modelling of diffusion processes. Cluster D encompasses 23 publications, including 2 book publications, and mainly includes elaborations on the modelling of diffusion processes building upon the Bass model. Similar to Cluster B, three publications of Rogers’ Diffusion of Innovation were excluded. Next, a small subset within Cluster D specifically focuses on the diffusion of agricultural innovations, the effect of policy intervention on diffusion, and the effect of diffusion on economic development.

Most of the articles in Cluster D can be related to the work of Frank M. Bass, after which the Bass Model has been named [35, 126, 127]. This research is closely related to early work of Griliches [36] and Mansfield [37] which can be found in Cluster A. Bass devised his model in 1969 in order to develop a theory of timing concerning the initial purchase of new consumer products. The Bass model is based on the assumption that "the probability of purchase at any time is related linearly to the number of previous buyers. [..] The model implies exponential growth of initial purchases to a peak and then exponential decay" (1969, p. 226). The model finds its theoretical background in mathematical models concerned with the social contagion of news. Since the early work of Bass several researchers have extensively explored which mechanisms constitute social contagion [128-130]. The strength of the Bass model lies in the forecasting opportunities based on predictions about timing and magnitude sales and, in particular, the sales peak (1969, p.226). In contrast to the spread of innovations in homogeneous social systems as assumed by the early 'diffusionists', Chatterjee and Eliashberg [131] were among the first to model the diffusion of innovation in a heterogeneous population (which had previously been suggested by Gatignon and Robertson [23]). Specific attention have been devoted to international (spatial) diffusion 
models taking into account country characteristics including cultural determinants [112, 115, 132].

Although the Bass model has often been criticized, today’s diffusion scholars continue to use the model; the renewed attention has been encouraged by several reviews and will be addressed in greater detail in Section 4.4 (Cluster 4) [113, 126, 133-136]. As a result diffusion models have been modified over time to improve their explanatory power (these modifications include the introduction of marketing variables in the parameterization of the models; generalizing the models to consider innovations at different stages of diffusion in different countries; and building models to consider the diffusion of successive generations of technology - particularly related to the diffusion of durables and communication technology) [135]. Nevertheless, diffusion scholars face several challenges regarding anticipating on market trends such as opening up of markets in developing countries, Web-based services, virtual social networks, and complex product-service structure [136]. In their review Meade and Islam (2006) suggest that future research should focus on forecasting new product diffusion with little or no data, forecasting with multinational models, and forecasting with multi-generation models [135]. In addition Peres et al. (2010) suggest that in order for diffusion to remain a state-of-the-art modelling framework, research should be devoted to include additional growth drivers (in addition to interpersonal communications as a parameter); re-examine the metrics to describe both the level and variety of usage; and extend the range of data sources [136].

Two small subsets of articles were identified within Cluster D. The first subset addresses the diffusion of agricultural innovations (often from a policy-making perspective) [137, 138]. In their article, Feder et al. [21] surveyed the adoption of agricultural innovation 
in developing countries. As demonstrated in Cluster 5 (see Section 4.5), this subset secured renewed interest by specifically addressing Feder et al. [21] notion of "diffusion dynamics”.

A second subset builds upon the effect of network ties with respect to social contagion and diffusion of innovation [139, 140]. It has been suggested that the tie strength between adopters (or non-adopters) being “structural equivalents” (i.e. very similar) is a predictor of innovation adoption. In this respect, Burt (1987) distincts between two types of diffusion models suggesting a debate between cohesion and structural equivalence models. Cohesion models build upon the notion that adopters resolve the uncertainty problem through conversations with peers in contrast to structural equivalence models which suggests that uncertainty of adoption is resolved through the perception of appropriate behaviour related to the social network position [140].

\subsection{Relative importance of the theoretical cornerstones}

The relative importance of the four cornerstones of innovation adoption have been assessed using citation-based statistics. Table 5 reveals that Cluster A (“Institutional theory and the legitimization of innovative behaviour ") and Cluster B ("Theory of Reasoned Action; Technology Acceptance Model”) received, on average, the most citations from the 1260 articles included in the innovation adoption dataset. On average, the references in Cluster A and Cluster B have both been cited 44 times while Clusters C and Cluster D obtain substantially less citations, 41 and 37 respectively. Only Cluster A and Cluster B have been cited more than the average citation number $(42,07)$.

However, the Web of Science database consists of articles where all clusters also include some highly cited book publications, and the citation statistics from 2003 to 2016 cannot be derived from this database [2, 3, 31, 32, 54, 68, 70, 73, 76, 77]. Books are therefore excluded from the citation impact analysis. 
Table 5: Indicators of publication output and citation impact (cited by the 1260 articles included in the dataset) per cluster of cited references

\begin{tabular}{|c|c|c|c|c|c|}
\hline Cluster & Label & $\begin{array}{l}\text { Number of } \\
\text { publications } \\
\text { (including } \\
\text { books) }\end{array}$ & Top 3 most-cited articles & $\begin{array}{l}\text { Average } \\
\text { number } \\
\text { of } \\
\text { citations } \\
\text { / article* }\end{array}$ & $\begin{array}{l}\text { Ratio to } \\
\text { average } \\
\text { (sample) } \\
*\end{array}$ \\
\hline A & $\begin{array}{l}\text { Institutional theory and the } \\
\text { legitimization of } \\
\text { innovative behaviour }\end{array}$ & 44 & $\begin{array}{l}\text { Dimaggio and Powell (1983) } \\
\text { [59]: 105; Cohen (1990) [44]: } \\
\text { 92; Griliches (1957) [36]: } 67\end{array}$ & 44,37 & 1482,57 \\
\hline $\mathrm{B}$ & $\begin{array}{l}\text { Theory of Reasoned } \\
\text { Action and the } \\
\text { Technology Acceptance } \\
\text { Model }\end{array}$ & 30 & $\begin{array}{l}\text { Davis (1989) [81]: 122; } \\
\text { Venkatesh et al. (2003) [17]: } \\
\text { 99; Davis et al. (1989) [82]: } 90\end{array}$ & 44,36 & 1444,77 \\
\hline $\mathrm{C}$ & $\begin{array}{l}\text { Determinants of } \\
\text { innovation adoption, an } \\
\text { econometric perspective }\end{array}$ & 35 & $\begin{array}{l}\text { Tornatzky and Klein (1982) } \\
\text { [20]: 97; Damanpour (1991) } \\
\text { [18]: 87; Cooper and Zmud } \\
\text { (1990) [96]: } 70\end{array}$ & 41,03 & 326,60 \\
\hline $\mathrm{D}$ & Diffusion Theory & 23 & $\begin{array}{l}\text { Bass (1969) [35]: 134; Feder et } \\
\text { al. (1985) [21]: 66; Mahajan et } \\
\text { al. (1990) [126]: } 57\end{array}$ & 36,67 & 739,78 \\
\hline & Total & 132 & & 42,07 & $\begin{array}{c}12 \\
01,95 \\
\end{array}$ \\
\hline
\end{tabular}

\section{ANALYSIS OF INNOVATION ADOPTION RESEARCH TRENDS BASED ON}

\section{BIBLIOGRAPHIC COUPLING}

In this section, we will unravel the current trends in the innovation adoption research by studying bibliographic coupling among the publications in our longitudinal dataset. Figure 6 illustrates a relatively coherent bibliographic network with five clusters of references cited by the 919 publications on innovation adoption published between 2003 and 2016. Clusters 1 to 4 are structured around a relative empty centre, which indicates that fields are more strongly tied than others [13]. Cluster 5, however, can be found in the periphery of the map with strong ties to Clusters 2 and 4 . In this respect, Cluster 5 is clearly separated from Clusters 1 and 3. The identified clusters are labelled as follows: Cluster 1 -drivers and impediments of information technology adoption; Cluster 2 - the adoption of technology 
standards; Cluster 3 - organizational rationales associated with innovation adoption; Cluster 4 - modelling the diffusion process; and Cluster 5 - adoption of agricultural innovations.

Table 6 presents an overview of the research trends reflected in Clusters 1 to 5 . We found that the research trends of the five clusters can be linked to a particular empirical field - Cluster 1 focuses on Information Technology, Cluster 2 focuses on technological standards, Cluster 3 focuses on management innovations, Cluster 4 on consumer durables and product innovations and Cluster 5 captures publications concerned with the adoption of agricultural economic innovations in developing nations. Column 4 highlights the theory on which it builds, with particular relevance to the theoretical cornerstones identified in Section 3. Cluster 1 builds upon Clusters B and C and specifically explores the determinants affecting the adoption and diffusion of IT innovations. Cluster 2 does not build upon a particular cluster identified in the previous section but explores the adoption of new and/or emerging technological standards related to sustainable technology. Theory development is principally related to technology trajectories; dominant designs and technology standards and the battle for dominance related to diffusion and change within a sector. Cluster 4 mainly takes into account the diffusion of consumer durables and product innovation; it focuses on the Bass Model that has been studied in many different fields. The "appendix", Cluster 5, addresses the dynamics of innovation adoption and diffusion. In the following section, we discuss the five clusters in greater depth adopting two perspectives: a representation of the field in which adoption has been studied, and the theoretical focus of the cluster. 
Table 6: Overview of the 5 identified bibliographic coupled clusters

\begin{tabular}{|l|l|l|l|}
\hline Cluster & $\begin{array}{l}\text { Builds } \\
\text { upon } \\
\text { cluster: }\end{array}$ & Field under study & Theory \\
\hline 1 & B \& C & Information technology & $\begin{array}{l}\text { Diffusion of Innovations (DOI); } \\
\text { Technology Acceptance Model (TAM) }\end{array}$ \\
\hline 2 & $\begin{array}{l}\text { None in } \\
\text { particular }\end{array}$ & $\begin{array}{l}\text { Technology standards (sustainable } \\
\text { technologies) }\end{array}$ & $\begin{array}{l}\text { Diffusion of Innovations (DOI); } \\
\text { Technology trajectories; dominant } \\
\text { design and technology standards; } \\
\text { complementarities and organizational } \\
\text { capabilities }\end{array}$ \\
\hline 3 & A & Management innovations & $\begin{array}{l}\text { Behavioural Theory of the Firm; } \\
\text { Institutional Logic }\end{array}$ \\
\hline 4 & D & $\begin{array}{l}\text { Consumer durables and product } \\
\text { innovation }\end{array}$ & Bass Model \\
\hline 5 & D & $\begin{array}{l}\text { Agriculture innovation (in developing } \\
\text { countries) }\end{array}$ & Duration Analysis \\
\hline
\end{tabular}

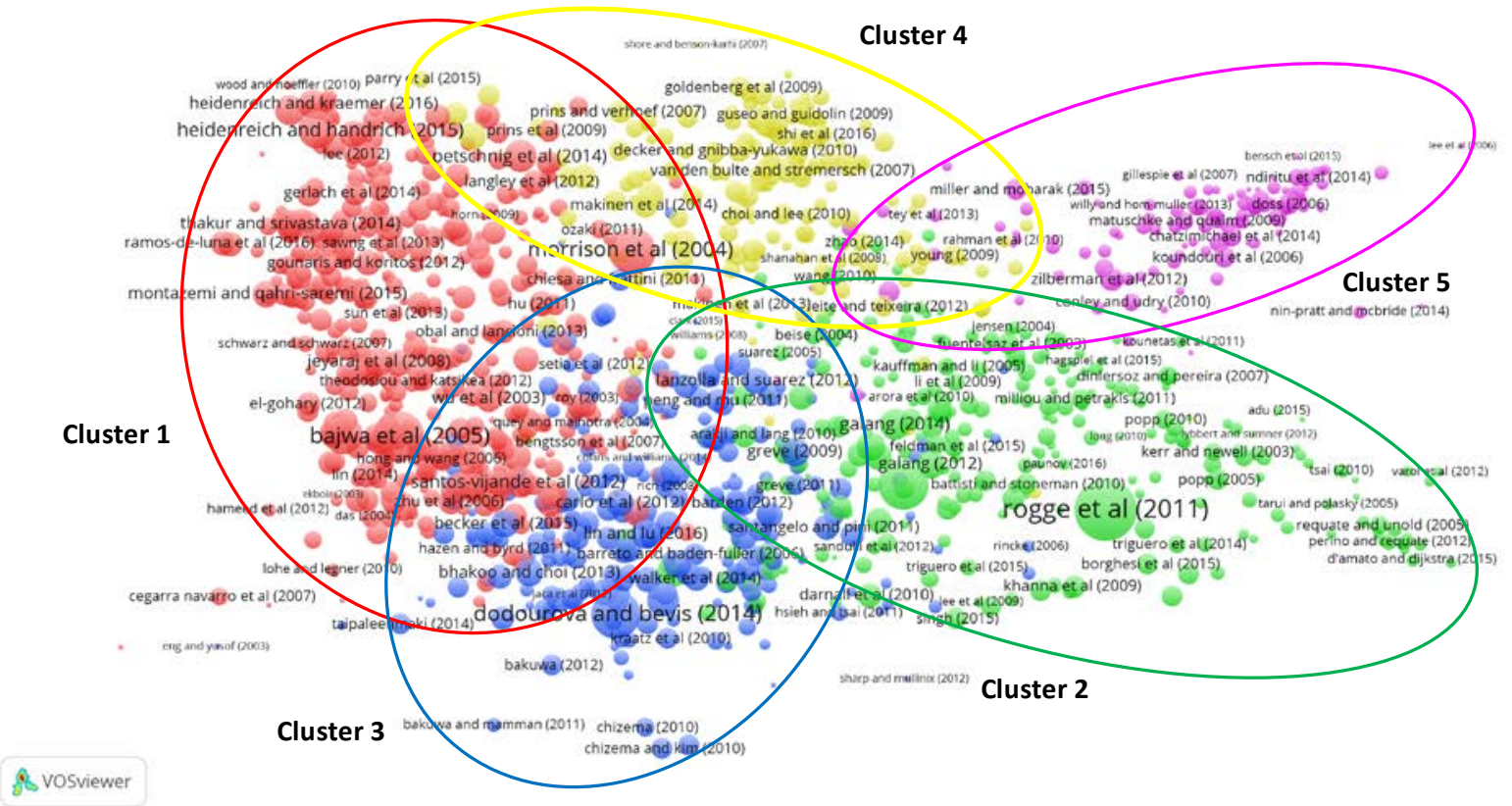

Figure 6: Bibliographic network of innovation adoption publications published between 2003 and 2016

\subsection{Cluster 1: Drivers and impediments of information technology adoption}

Cluster 1 includes 433 articles and captures research that we labelled: “Drivers and impediments of information technology adoption”. This cluster focuses mainly on the adoption of information technology and the determinants that impede or stimulate adoption.

Cluster 1 builds upon Clusters A and C, which were important theoretical cornerstones in Section 3. Moreover, the articles included in this cluster focus predominantly on the 
contextual drivers and impediments of IT adoption, while Clusters A and C provide uniform models to explore the determinants of technology acceptance and adoption. Recurring IT technologies of interest include: education and E-learning; computer technology and Internet; supply chain management technology and RFID; E-commerce, mobile IT and E-business. Based on the density view it was found that Cluster 1 contains the most important part of the bibliographic network. Based on the density view two research themes were identified that are related to the drivers and impediments of IT adoption. The first theme address the an individual's intention to accept and adopt an IT innovation. In contrast, the second theme studies the acceptance and adoption of IT innovations at the organizational level.

The articles in Cluster 1 focus chiefly on the evaluation of drivers and impediments of IT adoption, which corresponds to the characteristics of Cluster C (see Section 3.3). The adoption determinants related to IT adoption can be assigned to three well-established categories of variables: technology determinants; organizational determinants, and environmental determinants [141-144]. In this respect, some refer to Tornatzky and Fleisher's [100] Technology-Organization-Environment framework [145, 146].

In contrast to Cluster $\mathrm{C}$, a common feature of the articles in this cluster is that they specifically take into account the drivers and impediments of adoption associated with the distinct stages of adoption or the specific adoption context. More specifically, several publications in this cluster study the effects of a firm's environment or supply chain on subsequent stages of IT innovation adoption, including the effect of network externalities [125, 141, 147, 148]. Thus, Cluster 1 connects to the Downs and Mohr critique as discussed in section 3.3 (cluster C).

We also found a group of articles that draws on an established framework, the Technology Acceptance Model, as found in Cluster A (see Section 3.2) [149-151]. The Technology Acceptance Model and insights from the Theory of Planned Behaviour and the 
Theory of Reasoned Action have been applied to research both the adoption of IT by individuals and organizations. Several authors have tried to extend or even alter the model

while others have "borrowed” several adoption mechanisms from the Diffusion of Innovations, the Reasoned Action and Firm Behaviour line of debate in order to develop a more integrated model. As a result these authors integrated several innovation characteristics (compatibility, cost and perceived risk) from the Diffusion of Innovation Theory and determinants from Firm Behavioural Theory into the Technology Acceptance Model [152$155]$.

\subsection{Cluster 2: The adoption of technological standards}

Cluster 2 includes 267 articles and the research trend it represents is labelled as: "The adoption of technological standards”. This cluster deals with technological change that overturns existing technological standards of which some are considered as General Purpose Technology, i.e. innovation relevant to a wide range of industries and subsequently changes modes of production and operation [156-158]. Subsequently, the key question is how these newer technological standards will be adopted as well as to what extend (depth of adoption). Cluster 2 does not build upon a particular cluster identified as a theoretical cornerstone in Section 3. The articles within this cluster primarily studied adoption (timing) of new technological standards from an econometric point of view and expressed in mathematical representations. Surprisingly, the most cited articles were located in the periphery of the cluster and, with a few exceptions, focus on technology change instruments (i.e. policies) that sustain the transition of standards.

The common thread in the first research stream derived from the articles is that they assume that technology adoption involves three decisions including [159]: 1) whether to adopt or not, 2) extend of exploiting the innovation (depth of adoption), and 3) replacement 
speed of old by the new technology. Subsequently, different models have been developed to address these research questions (see Table7). Next, attempts have been made to develop a diffusion model which includes both inter-firm diffusion concerning the adoption decision as well as the intra-firm diffusion with respect to the depth of adoption and includes determinants related to rank, epidemic, stock and order effects [48, 159-163]. More precisely, these determinants include firm characteristics (including technical prerequisites and absorptive capacity), environment and industry characteristics, epidemic or learning effects and the cost and benefits of usage. It is assumed that these determinants reflect both inter and intra-firm diffusion [163].

Some scholars have assessed some of the previous aspects more specifically related to innovation diffusion. Building upon the work of Milgorm and Roberts [164, 165], Bocquet [166] emphasized that the adoption is not merely affected by traditional adoption variables but also by complementarities between organizational characteristics concerning strategies, organization and information technologies. The complementarity or supermodularity view assumes that the adoption of a new technology only contributes to organizational performance if it matches with other organizational practices. In this line of reasoning similar findings have been reported by Fabiani [157] who claims that adoption is just one comport of a complex process of change. Furthermore, it has been emphasized that complementarities between multiple technologies should be taken into account while it could affect the adoption decision of (multiple) technologies when it complements or substitutes a technology [167169]. Next, to enable adoption, to develop complementary assets and capabilities and to benefit from innovation, organizations need to learn to adjust the organization to the innovation which it intends to adopt [170]. 
Table 7: Articles of Cluster 2 address the battle for dominance between two technology standards and focus on one of the five research questions.

\begin{tabular}{|l|l|}
\hline Research question & Model \\
\hline Whether and when to adopt? & Real Options Model [171, 172] \\
\hline $\begin{array}{l}\text { When to adopt a new network externalities technology? } \\
\text { How to break through technology standards and speed up the diffusion } \\
\text { of new technology standards? }\end{array}$ & Discrete Choice Model [173, 174] \\
\hline $\begin{array}{l}\text { What is the effect of time-related variables on adoption during a) the } \\
\text { subsequent stages of individual decision making, or b) the subsequent } \\
\text { stages of diffusion? }\end{array}$ & Duration Analysis Model [175, 176] \\
\hline Whether and when to invest in adoption? & Dynamic Investment Game Model [177] \\
\hline $\begin{array}{l}\text { Which thresholds have to be taken into account during the diffusion of } \\
\text { a new standard and when? }\end{array}$ & Threshold Model [178] \\
\hline
\end{tabular}

Second, with respect to the adoption of technology standards, the most cited articles in Cluster 2 focus on the effect of policy instruments on adoption and, more specifically, on the context of environmentally friendly technology. In particular, policies that stimulate the development and adoption of environmentally beneficial technology has earned considerable attention. Scholars have applied integral conceptualizations to study the effect of governmental policies on adoption by focusing on the nexus between technology and environmental policies [179-182] and on the nexus between incentive- and prescriptiveoriented policy instruments [183, 184]. Several articles address the adoption of environmental innovation at the global level, where environmental innovations diffuse internationally [185187].

\subsection{Cluster 3: Organizational rationales associated with innovation adoption}

Cluster 3 includes 258 articles: the research trend it represents has been labelled as: “Organizational rationales associated with innovation adoption”. Cluster 3 has a common focus on the institutionalization of management systems such as the adoption of Management Control Systems (MCS) [188], High Performance Work Organizations [189] including Lean management techniques [190] and Performance Management among sub-units within a 
multinational [191]. Cluster 3 is nestled between cluster 1 and 2 in the map. From this it can be derived that while management innovations are often adopted together with or complementary to IT and technology innovation (subsequently cluster 1 and 2), these research fields are closely positioned next to each other.

Why do organizations innovate? More specifically, why do organizations decide to (or intent to) adopt and subsequently implement innovations? The articles included in cluster 3 build upon the Schumpeterian law that innovation is deemed necessary with respect to competitive advantage and economic growth. Cluster 3 in particular links organizational practices to adoption emphasizing that traditional economic factors only explain a limited proportion of the variability of innovation adoption across firms. This notion has led to the suggestion that it is necessary to consider alternative explanations building upon the organizational rationality and routines as can be found in theory about evolutionary economics and institutional change [192, 193]. Moreover, recently the work of Birkinshaw, Hamel and Mol [194] made scholars consider that management innovations enable the adoption of technological innovation as organizations need to build capabilities to do so [195, 196].

Traditional adoption research has tended to emphasize the importance of innovation characteristics, in terms of economic efficiency, on the decision-making process leading to adoption, referred to as the "pro-innovation bias" [3, 197]. Moreover, following the theoretical cornerstone of Cluster D, articles in this cluster have contributed to several "subtheories” related to the Behavioural Theory of the Firm [33] including neo-institutional theory and the Resource-Based View. Neo-institutional scholars Barreto and Baden-Fuller [198] identified the following lacunas in the literature with respect to innovative firm behaviour: 1) who imitates whom? 2) do imitating firms distinguish between "good" and "bad" options? and 3) what is the effect of mimic isomorphism on firm performance? Barreto 
and Baden-Fuller suggest that organizations apply a legitimacy-driven framework when imitating legitimacy providers, which act as “reference points” or "guides” in a complex and hostile firm environment [198]. Thus, gaining legitimacy has a substantial effect on organizational decision making. Moreover, a dualism between “pressure to conform” and "pressure to perform” can be noted, according to these authors.

Several articles build upon theoretical concepts embedded in Neo-institutional theory and have assessed the habits [199]; memetics [200]; logic [201]; meaning [202], vision [203], analogies [204], and rationales [205] related to innovation adoption. In addition, as witnessed in Cluster D, Abrahamson [34, 206] introduced the concept of "management fashion”, which has been further explored by Baskerville and Myers [207] and Wang [208]. Following Baskerville and Myers, management fashion is defined as "a relatively transitory belief that a certain management technique leads rational management progress” (p.647). From the Neo-Institutional perspective, management-setting organisations, which are by definition located outside the group of followers, shape the belief that certain management practices are rational, state-of-the-art and "the right thing to do", and that subsequently they will be imitated by fashion followers. Addressing the innovation-diffusion perspective and, in particular, the pro-innovation bias, some organizations imitate fashionable innovations under conditions of uncertainty concerning environmental forces, organizational goals and efficiency, even when they have no utility for the imitating organization [34, 206-208].

From a Behavioural Theoretical standpoint, some studies attempted to combine several theoretical perspectives into an integrative framework. Basaglia et al. [209], for example, integrated the institutional-, management fashion-, and efficient-choice perspectives into a single theoretical model. Furthermore, Cheng [201] addressed both institutional and organizational learning theory. Massini, Lewin and Greve [210] attempted to align Behavioural Theory and Institutional Theory. Another group of scholars have drawn upon the 
Resource-Based View (RBV) of organizations and considered the effect of organizational resources, social network ties and learning capabilities on adoption [211-213]. Again, these publications build upon the theoretical assumptions in Cluster D.

\subsection{Cluster 4: Modelling the diffusion process}

Cluster 4 includes 180 articles; the research trend it represents has been labelled as: "Modelling the diffusion process". The articles in Cluster 4 all focus on mathematical representations of the innovation-diffusion process building upon the theoretical assumptions of Cluster B. Compared to the previously discussed clusters, Cluster 4 is not related to any specific field, while the model is applicable to an evaluation of a wide variety of innovations within diverse industries and sectors. Nevertheless it was found that many articles in Cluster 4 researched the diffusion of durables and product innovations.

The bulk of articles included in Cluster 4 deal with revising the Bass Model. The Bass Model has been criticised from the outset by scholars claiming that the model is too simplistic. Adjustments and additions have been suggested such as incorporating price development and marketing indicators [214, 215]. Recent studies have further refined the Bass Model to better forecast and describe diffusion by addressing the dynamics of diffusion including the effects empowered by policies, social network structure and heterogeneity and product evolution. Moreover, research about diffusion dynamics have addressed issues about how dynamic communication networks among adopters affect knowledge distribution and related innovation adoption [216-218] and the effect of incremental improvement or evolutionary innovation [219, 220]. For example, Rahmandad and Sterman [221] discussed when to apply agent-based $(\mathrm{AB})$ models and when to opt for differential equation models (DE) while modelling dynamic diffusion processes, taking into account network structure and heterogeneity (examples of both can be found in Cluster 4). 
Building on the Bass Model, the authors of the highest cited articles in this cluster have focused on the effect of social contagion, referred to as "social influence" or "social learning”, and the effect of social heterogeneity on diffusion [128, 130, 222-225]. For example, Van den Bulte and Stremersch’s (2004, p.530) definition of social contagion refers to actors' adoption as ' $a$ function of their exposure to other actors' knowledge, attitudes, or behaviours concerning the new product" [130]. Moreover, viral marketing builds on the characteristics of social contagion and especially (electronic) word-of-mouth [226, 227]. De Bruyn and Lilien [227], for example, studied the role that word of mouth and the effect of social tie characteristics plays during each stage of decision making.

Other themes have been studied as well. First, several authors focused on countryspecific effects on innovation adoption and on innovation spill over between countries [228230]. Next, some scholars took into account network externality effects. Fornerino [231], for example, applied the Non-Uniform Influence (NUI) Model developed by Easingwood, Mahajan and Muller [232] to study the diffusion of the Internet in France. The NUI equations differ from the Bass equation in that it takes into account an (exponential) enhanced influence of interpersonal communication.

\subsection{Cluster 5: Adoption of agricultural innovations}

Cluster 5 includes 112 articles; the research trend it represents have been labelled: “Adoption of agricultural innovations". The cluster can be found in the periphery of the network close to Clusters 2 and 4 and at arm's length from Clusters 1 and 3. More precisely, it is unlikely that Cluster 5 is cited with Clusters 1 and 3. The articles in Cluster 5 address innovation adoption-diffusion from an economic theory perspective. A large set of articles in Cluster 5 consider the effect of technology adoption on economic growth and increased welfare in developing countries. In general, these technologies encompass agricultural 
innovations such as fertilizers, intercropping, and the use of new (bio-engineered) seed varieties. Moreover, several articles focus on the impact of technology adoption on efforts to reduce the environmental impact of agricultural practices such as organic farming [233] and conservation tillage [234, 235]. Finally, some studies deal with innovations that reduce environmental impact and increase the economic performance of biotechnology.

An influential review often referenced in articles in Cluster 5 is the article by Feder, Just and Zilberman [21]. Several publications in Cluster 5 address Feder, Just and Zilbermann's notion of “the dynamics of adoption” [234, 236-239]. This review in particular shows how Cluster 5 relates to Cluster 4 . In line with this review, a distinction can be made between adoption studies modelling the adoption of an innovation at a specific point in time and diffusion studies that model the cumulative dissemination of an innovation. Following Davies [240], the criticism has been made that many adoption models depend on crosssectional data and neglect the impact of time-dependent determinants such as price variation over time. To address this critique, several scholars in this cluster used Duration Analysis (historically used to model epidemiological phenomena) including both cross-sectional and time-series determinants [236].

Several dimensions of adoption dynamics have been addressed, such as the importance of learning, information acquisition, and personal perceptions that effect change over time because its inherent value changes [234]. Some authors implicitly address the adoption dynamics bias. For example, Conley and Udry [241], the most cited article in Cluster 5, developed a model that takes into account the role of social learning in the diffusion of new agricultural technology - an approach that is closely related to the social contagion concept (see Cluster 4). Others have focused on the determinants that lead to “disadoption”, i.e. discontinuance or abandonment, which is considered to be another dynamic dimension [237-239]. Some methodological issues related to this line of debate have 
been addressed by Diagne and Demont [242] and Doss [243]. Diagne and Demond [242] address two types of bias related to commonly used adoption rates estimators, and Doss [243] conducted an extensive literature review suggesting alternative approaches to designing technology adoption studies, referred to as the second generation of agricultural innovation diffusion research.

\subsection{Relative importance of bibliographic-coupled clusters}

Table 6 presents some citation-based statistics to assess the relative importance of the five clusters identified. Table 8 shows that Cluster 1 received the most citations per article by far, in contrast to Cluster 3 which seems to be a less popular research trend. The conclusion holds if one controls for the number of publications per cluster or for the average number of citations per article per year. Thus, Cluster 1 on the "Drivers and impediments of information technology (IT) adoption" can be pinpointed as the most cited cluster, with Cluster 2 ("The adoption of technological standards”) having an average impact.

Figure 7 shows the number of publications per cluster from 2003 to 2016. Cluster 2, 3 and 4 have trend lines with both peaks and saddles. Cluster 5 , the smallest cluster with a relative low impact, shows a relatively stable pattern. Cluster 1 shows a steady grow of articles per year up till 2010. After 2010 this research trend seems to lose the interest of scholars with a drop in the number of publications. In general, the total number of articles published per year in the field of innovation adoption dropped in 2013 after which the number publications increased again on a yearly bases (for the year 2016, from January to October about 80 scientific articles have been published). 
Table 8: Indicators of publication output and citation impact per thematic cluster

\begin{tabular}{|c|c|c|c|c|c|}
\hline Cluster & $\begin{array}{l}\text { Number of } \\
\text { articles }\end{array}$ & Average age & $\begin{array}{l}\text { Total number of } \\
\text { citations }\end{array}$ & $\begin{array}{l}\text { Average number } \\
\text { of citations/ } \\
\text { article }\end{array}$ & $\begin{array}{l}\text { Average number } \\
\text { of citations/ } \\
\text { article/year }\end{array}$ \\
\hline 1 & 432 & 4,88 & 5028 & 11,64 & 2,39 \\
\hline 2 & 267 & 5,03 & 2332 & 8,73 & 1,74 \\
\hline 3 & 258 & 3,93 & 1311 & 5,08 & 1,29 \\
\hline 4 & 180 & 4,68 & 1405 & 7,81 & 1,67 \\
\hline 5 & 113 & 5,42 & 860 & 7,61 & 1,41 \\
\hline Total & 1250 & 4,70 & 10936 & 8,75 & 1,86 \\
\hline
\end{tabular}

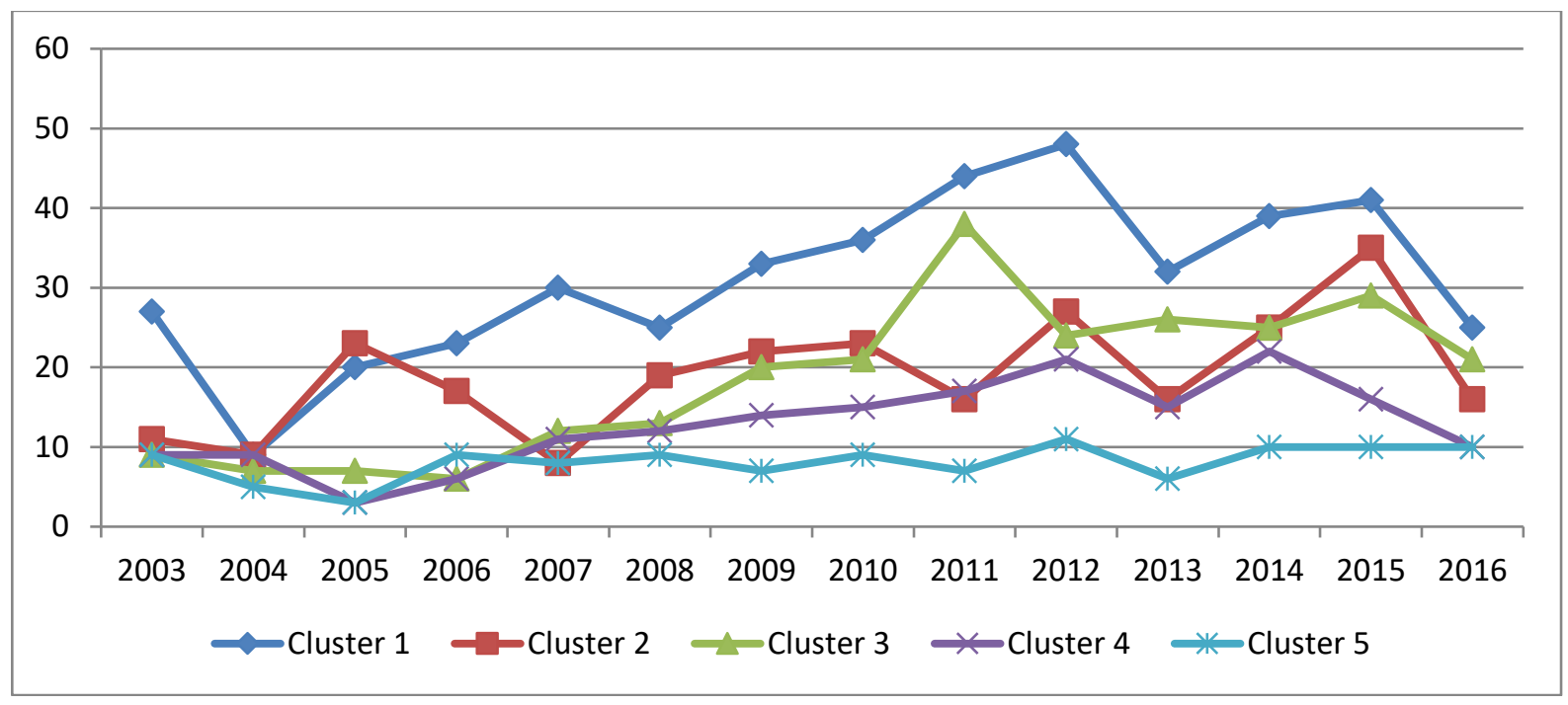

Figure 7: Number of publications per year per cluster.

One could wonder how this bibliometric study confirm or dispel from previous reviews of the innovation adoption literature. Therefore we compared the findings with innovation adoption reviews which are published in the period 2013-2017. By consulting the WoS database we identified 1 bibliometric review, 2 scoping reviews, 4 meta-analyses, and 42 systematic, qualitative reviews. After close examination of the theoretical concepts and field of study, three observations were made. First, we found that 13 reviews could not be linked to a particular theoretical framework, i.e. these reviews aim at providing an overview of the variables affecting the adoption-diffusion of innovation. Second, out of these 49 studies, 34 articles include one or several theoretical frameworks linked to the adoption of innovation within a specific field. Finally, 47 reviews could be linked to the adoption of innovation within specific fields: health care (11); eco-innovation and agriculture (16); information and 
communication technology (9); business economics and new product introduction (11). In line with Wong et al. (2010) and Wisdom et al. (2014) we consider these reviews as efforts to constitute 'middle-range theories' of innovation adoption [244, 245].

Next, the 2 remaining reviews which we identified could not be linked to a specific research field (i.e.[246, 247]). Kapoor et al. (2014) reviewed Rogers’ innovation adoption attributes in order to develop a guideline to the ideal innovation-attribute studies. Sriwannawit and Sandström (2015) conducted a bibliometric analysis of innovation diffusion literature and identified 13 clusters, comprising 6,811 publications over the period of 20022011. The main difference with our bibliometric review encompass the distinction between theoretical cornerstones and recent research trends in innovation adoption research, i.e. some of the clusters identified by Sriwannawit and Sandström are considered as theoretical cornerstones in this review rather than current research trends. In our study we applied two distinct bibliometric approaches to distinct between theoretical cornerstones and research trends which are subsequently explicitly linked to each other.

Based on the theoretical concepts and field of study we cross referenced the 48 reviews with the theoretical cornerstones and research trends identified in this bibliometric study. Therefore we constructed the framework as illustrated in figure 7 . This analysis shows that the theoretical cornerstones and research trends identified are robust while we were also able to cross reference the review articles with our bibliographic study. While most of the identified reviews are considered middle-range theories of innovation adoption, this framework contributes by organizing the middle-range theories of innovation adoption. A parallel contribution of our bibliometric study is that it confirms that previous, mostly qualitative reviews, contribute to 'disentangle the forest of scientific publications' about innovation adoption. In line with previously conducted bibliometric studies [10, 11], both 


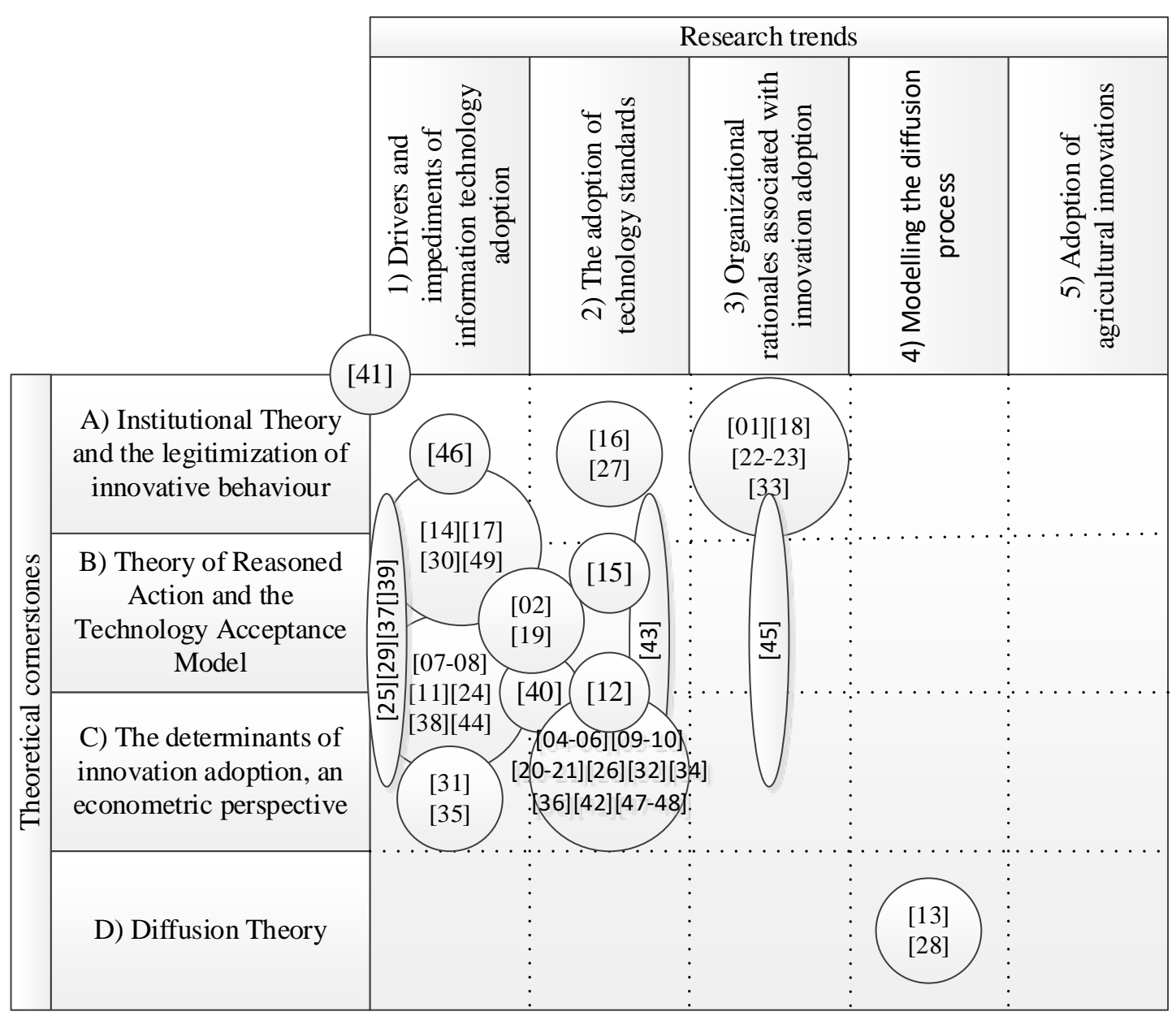

\begin{tabular}{|l|l|l|l|l|l|}
\hline$[01]$ & Aarikka-Stenroos et al. (2014) [248] & {$[18]$} & Innes et al. (2015) [249] & {$[35]$} & Radu (2016) [250] \\
\hline$[02]$ & Adnan et al. (2017a-b-c) [251-253] & {$[19]$} & Kapoor et al. (2014) [246] & {$[36]$} & Rahbauer et al. (2016) [254] \\
\hline$[03]$ & Allen et al. (2017) [255] & {$[20]$} & Karakaya \& Sriwannawit (2015) [256] & {$[37]$} & Rana et al. (2015) [257] \\
\hline$[04]$ & Bossle et al. (2016) [258] & {$[21]$} & Karakaya et al. (2014) [259] & {$[38]$} & Rezvani et al. (2015) [260] \\
\hline$[05]$ & Byambaa et al. (2015) [261] & {$[22]$} & Kelly et al. (2017) [262] & {$[39]$} & Sanakulov \& Karjaluoto (2015) [263] \\
\hline$[06]$ & Candas et al. (2016) [264] & {$[23]$} & Khanassov et al. (2014) [265] & {$[40]$} & Sovacool and Hess (2017) [266] \\
\hline$[07]$ & Cresswell and Sheikh (2013) [267] & {$[24]$} & Khong et al. (2015) [268] & {$[41]$} & Sriwannawit \& Sandström (2015) [247] \\
\hline$[08]$ & De Grood et al. (2016) [269] & {$[25]$} & Kruse et al. (2014) [270] & {$[$ [42] } & Tayouga and Gagne (2016) [271] \\
\hline$[09]$ & Ellabban \& Abu-Rub (2016) [272] & {$[26]$} & Lefebvre et al. (2015) [273] & {$[43]$} & Varabyova et al. (2017) [274] \\
\hline$[10]$ & Estem et al. (2016) [275] & {$[27]$} & Lyle (2015) [276] & {$[44]$} & Williams et al. (2015) [277] \\
\hline$[11]$ & Gagnon et al. (2015) [278] & {$[28]$} & Moglia et al. (2017) [279] & {$[45]$} & Wisdom et al. (2014) [245] \\
\hline$[12]$ & Gangwar et al. (2013) [280] & {$[29]$} & Molinillo \& Japutra (2017) [281] & {$[46]$} & Wu (2016) [282] \\
\hline$[13]$ & Goodwin et al. (2014) [283] & {$[30]$} & Montazemi \& Qahri-Saremi (2015) [284] & {$[47]$} & Yeatts et al. (2017) [285] \\
\hline$[14]$ & Hanafizadeh (2013) [286] & {$[31]$} & Mwirigi et al. (2014) [287] & {$[48]$} & Zanello et al. (2016) [288] \\
\hline$[15]$ & Hasler et al. (2017) [289] & {$[32]$} & Nejad et al. (2014) [290] & {$[49]$} & Zhang et al. (2014) [291] \\
\hline$[16]$ & Hojnik \& Ruzzier (2016) [292] & {$[33]$} & Novins et al. (2013) [293] & \\
\hline$[17]$ & Ingebrigtsen et al. (2014) [294] & {$[34]$} & Ortiz et al. (2017) [295] &
\end{tabular}

Figure 7: Cross reference of 49 recently published reviews with the theoretical cornerstones and research trends of innovation adoption research 


\section{SUMMARY, FUTURE RESEARCH AND LIMITATIONS}

\subsection{Summary}

In the previous sections, we presented a novel, systematic and comprehensive review of the bibliographic literature (including 1260 articles) to identify the theoretical cornerstones and research trends in innovation adoption research. This study complements existing reviews in various ways. First, based on co-citation analysis, we illustrate that innovation adoption research is built on four theoretical cornerstones (or in terms of bibliographic clustering, four clusters of prior publications): A) Institutional Theory and the legitimization of innovative behaviour; B) Theory of Reasoned Action and the Technology Acceptance Model; C) The determinants of innovation adoption, an econometric perspective; and D) Diffusion Theory.

Second, bibliographic coupling was used to assess the current research trends in the innovation adoption literature. This review is the first to identify thematic areas in an exhaustive manner. The bibliographic coupling technique revealed five clusters of thematic related publications or "research trends": 1) Drivers and impediments of information technology adoption; 2) The adoption of technological standards; 3) Organizational rationales associated with innovation adoption; 4) Modelling the diffusion process and; 5) Adoption of agricultural innovations. Within the bibliographic network, one of the clusters, Cluster 5, can be found in the periphery of the structure. It appears that Cluster 5 cannot be regarded as a mainstream thematic area as it is so closely related to Clusters 2 and 4.

Third, we were able to construct a coherent framework to assess the relevance of innovation adoption research by integrating the theoretical cornerstones and the current research trends. As a parallel contribution we found that previous conducted overview studies 
contributed to a coherent understanding of innovation adoption in specific fields and are bound together by the present bibliometric study.

\subsection{Future research}

In this section we present several important areas in the field of innovation adoption and diffusion that merit future research.

The development of more holistic theoretical explanations in the field of innovation adoption and diffusion. This bibliometric review revealed that adoption and diffusion research is highly segregated. Researchers mostly build upon conceptualizations related to a single research stream, which are often applied to explain the adoption of specific innovations within a single context. To create more holistic theoretical explanations of innovation adoption and diffusion, we would encourage future studies to investigate the adoption and diffusion mechanisms related to specific innovations across different contexts.

Detailed investigations of the distinguished research streams. The identified research streams include up to 400 articles, and thus encompass multiple theoretical concepts, which could be subject to fine grained content analysis [296]. Every single research stream encompasses multiple articles which could be assessed by applying bibliometric and text mining techniques as has been demonstrated by Randhawa et al. [9] in their literature review about open innovation and which includes 321 journal articles about open innovation.

Exploration of the explanatory power of psychological and organizational theories.

Despite the maturity of the field of innovation adoption research we suggest to further explore other theoretical perspectives used in e.g. management, marketing and organization behaviour which have not received much attention yet in the field of innovation adoption research. Doing so can help to further advance our understanding of innovation adoption. As a first example, while adoption involves decision-making, we expected that cognitive 
processes underlying human thought, knowledge and decision-making would hold a more prominent position in innovation adoption research. Theoretical concepts such as prospect theory [248-250], bounded rationality [252] and stakeholder theory [253] may help to understand which heuristics decision makers apply when considering the adoption of a specific innovation.

A second example of an underused theory concerns the innovation systems theory. This theory emphasizes that innovation systems should be considered as an important determinant of transition and change within an industry sector [297]. Innovation system research builds on the notion that (technological) niche innovations alone are not enough to sustain change but require subsequent innovations in the social domain to pave the way. Innovation and change in the social domain shape user practices, regulation and standards, and industry networks which create technological transition and socio-technical transformation [298].

An empirical lens to identify white spots in innovation adoption literature. Given the growing importance and attention in the last decade for service innovation research, we would also expect an increased stream of research about the potential adoption of service innovations. With a focus on the potential adoption of IT Innovations, Cluster 1 addresses an important, yet only limited subset of potential research in the adoption of service innovations. Also the question how IT as an enabler could stimulate the adoption of new products and services, still remains unanswered. While Cluster 2 and 3 reveal the results of research on the enabling effects of complementary innovations and (organizational) capabilities, research on the enabling effect of IT on the adoption of innovations may still be considered as a white spot in literature. A final suggestion for future research is related to the use of modularity principles and the application of product and process platforms in the industry. While we observe a substantial increase of research in this field, literature about the adoption dynamics 
and the mechanisms which drive the adoption and diffusion of module and platforms based innovations are still limited.

\subsection{Limitations}

Through the use of a bibliometric review methodology, this study reduced the bias that is often associated with expert surveys and traditional reviews [9]. Nevertheless, a limitation of this review is the direct consequence of the application of a bibliometric review methodology. Despite its advantages to overcome bias, bibliometric analyses cannot replace, rather merely complement, extensive reading and fine-grained content analyses [296, 299]. Based on 1260 journal articles referring to almost 46,000 publications, it is hardly possible to extensively discuss all the (middle range) theoretical concepts revealed by all these articles. Therefore, this review is limited to the identification of the theoretical cornerstones and main research trends in the field of innovation adoption, acceptance and diffusion. 


\section{REFERENCES}

\section{The full list of references contains over 1260 articles with 45,932 references and can be send by the authors upon request.}

[1] G. Tarde, The laws of imitation, trans, EC Parsons. New York: Henry, Holt, (1903).

[2] E.M. Rogers, Diffusion of innovations, Free Press of Glencoe, 1962.

[3] E.M. Rogers, Diffusion of Innovations, 5th ed., New York: Free Press, 2003.

[4] A.K. Gupta, P.E. Tesluk, M.S. Taylor, Innovation at and across multiple levels of analysis, Organization Science, 18 (2007) pp. 885-897.

[5] J. Fagerberg, B. Verspagen, Innovation, growth and economic development: have the conditions for catch-up changed?, International Journal of Technological Learning, Innovation and Development, 1 (2007) pp. 13-33.

[6] M.M. Keupp, M. Palmié, O. Gassmann, The strategic management of innovation: a systematic review and paths for future research, International Journal of Management Reviews, 14 (2012) pp. 367-390.

[7] J. Tidd, Innovation management in context: environment, organization and performance, International Journal of Management Reviews, 3 (2001) pp. 169-183.

[8] T. Greenhalgh, G. Robert, F. Macfarlane, P. Bate, O. Kyriakidou, Diffusion of innovations in service organizations: systematic review and recommendations, Milbank Quarterly, 82 (2004) pp. 581-629.

[9] A. Kovacs, B. Van Looy, B. Cassiman, Exploring the scope of open innovation: a bibliometric review of a decade of research, Scientometrics, 104 (2015) 951-983.

[10] G. Marzi, M. Dabić, T. Daim, E. Garces, Product and process innovation in manufacturing firms: a 30-year bibliometric analysis, Scientometrics, 113 (2017) 673-704.

[11] O. Furrer, H. Thomas, A. Goussevskaia, The structure and evolution of the strategic management field: A content analysis of 26 years of strategic management research, International Journal of Management Reviews, 10 (2008) 1-23.

[12] R. Vogel, W.H. Güttel, The dynamic capability view in strategic management: a bibliometric review, International Journal of Management Reviews, 15 (2013) pp. 426-446.

[13] N.J. Van Eck, L. Waltman, Software survey: VOSviewer, a computer program for bibliometric mapping, Scientometrics, 84 (2010) pp. 523-538.

[14] A. Kovacs, B. Van Looy, B. Cassiman, Exploring the scope of open innovation: a bibliometric review of a decade of research, Scientometrics, 104 (2015) pp. 951-983.

[15] J.A. Keizer, J.I.M. Halman, Risks in major innovation projects, a multiple case study within a world's leading company in the fast moving consumer goods, International Journal of Technology Management, 48 (2009) pp. 499-517.

[16] M.E. Falagas, E.I. Pitsouni, G.A. Malietzis, G. Pappas, Comparison of PubMed, Scopus, web of science, and Google scholar: strengths and weaknesses, The FASEB journal, 22 (2008) 338-342.

[17] V. Venkatesh, M.G. Morris, G.B. Davis, F.D. Davis, User acceptance of information technology: Toward a unified view, MIS quarterly, (2003) pp. 425-478.

[18] F. Damanpour, Organizational innovation: A meta-analysis of effects of determinants and moderators, Academy of Management Journal, (1991) pp. 555-590.

[19] P. Legris, J. Ingham, P. Collerette, Why do people use information technology? A critical review of the technology acceptance model, Information \& management, 40 (2003) 191-204.

[20] L.G. Tornatzky, K.J. Klein, Innovation characteristics and innovation adoptionimplementation: A meta-analysis of findings, IEEE Transactions on engineering management, 29 (1982) pp. 28-45. 
[21] G. Feder, R.E. Just, D. Zilberman, Adoption of agricultural innovations in developing countries: A survey, Economic development and cultural change, 33 (1985) pp. 255-298.

[22] P.A. Geroski, Models of technology diffusion, Research policy, 29 (2000) pp. 603-625.

[23] H. Gatignon, T.S. Robertson, A propositional inventory for new diffusion research, Journal of Consumer research, (1985) pp. 849-867.

[24] R.A. Wolfe, Organizational Innovation: Review, Critique and Suggested Research Directions*, Journal of Management Studies, 31 (1994) 405-431.

[25] R.T. Frambach, N. Schillewaert, Organizational innovation adoption: a multi-level framework of determinants and opportunities for future research, Journal of Business Research, 55 (2002) 163-176.

[26] D.J. Cook, C.D. Mulrow, R.B. Haynes, Systematic reviews: synthesis of best evidence for clinical decisions, Annals of internal medicine, 126 (1997) pp. 376-380.

[27] D.R. Tranfield, D. Denyer, P. Smart, Towards a methodology for developing evidenceinformed management knowledge by means of systematic review, British Journal of Management, 14 (2003) pp. 207-222.

[28] R. Bricker, An empirical investigation of the structure of accounting research, Journal of Accounting Research, (1989) pp 246-262.

[29] K.W. Boyack, R. Klavans, Co-citation analysis, bibliographic coupling, and direct citation: Which citation approach represents the research front most accurately?, Journal of the American Society for Information Science and Technology, 61 (2010) pp. 2389-2404.

[30] M.E. Newman, M. Girvan, Finding and evaluating community structure in networks, Physical review E, 69 (2004) pp. 026113.

[31] E.M. Rogers, Diffusion of innovations, 3th ed., New York, 1983.

[32] E.M. Rogers, Diffusion of innovations, 4th ed., New York, 1995.

[33] L. Argote, H.R. Greve, A behavioral theory of the firm-40 years and counting: Introduction and impact, Organization science, 18 (2007) pp. 337-349.

[34] E. Abrahamson, Managerial fads and fashions: The diffusion and rejection of innovations, Academy of Management Review, 16 (1991) pp. 586-612.

[35] F. Bass, A New Product Growth Model for Consumer Durables. Management Sciences, Institute for Operations Research and the Management Sciences. Evanston, XV (5), (1969).

[36] Z. Griliches, Hybrid corn: An exploration in the economics of technological change, Econometrica, Journal of the Econometric Society, (1957) pp. 501-522.

[37] E. Mansfield, Technical change and the rate of imitation, Econometrica: Journal of the Econometric Society, (1961) pp. 741-766.

[38] E. Mansfield, Industrial research and technological innovation; an econometric analysis, (1968).

[39] M.L. Katz, C. Shapiro, Network externalities, competition, and compatibility, The American economic review, 75 (1985) pp. 424-440.

[40] J. Farrell, G. Saloner, Standardization, compatibility, and innovation, The RAND Journal of Economics, (1985) pp. 70-83.

[41] J. Farrell, G. Saloner, Installed base and compatibility: Innovation, product preannouncements, and predation, The American economic review, (1986) pp. 940-955.

[42] P. Milgrom, J. Roberts, The economics of modern manufacturing: Technology, strategy, and organization, The American economic review, (1990) 511-528.

[43] W.M. Cohen, D.A. Levinthal, Innovation and learning: the two faces of R \& D, The Economic Journal, (1989) 569-596.

[44] W.M. Cohen, D.A. Levinthal, Absorptive capacity: a new perspective on learning and innovation, Administrative science quarterly, (1990) 128-152.

[45] D.J. Teece, G. Pisano, A. Shuen, Dynamic capabilities and strategic management, Strategic management journal, (1997) 509-533. 
[46] T.F. Bresnahan, E. Brynjolfsson, L.M. Hitt, Technology, Organization, and the Demand for Skilled Labor, in: M.M. Blair, T.A. Kochan (Eds.) The new relationship: Human capital in the American corporation, Brookings Institution Press, 2002, pp. pp. 145-193.

[47] R. Jensen, Adoption and diffusion of an innovation of uncertain profitability, Journal of economic theory, 27 (1982) pp. 182-193.

[48] M. Karshenas, P.L. Stoneman, Rank, stock, order, and epidemic effects in the diffusion of new process technologies: An empirical model, The RAND Journal of Economics, (1993) pp. 503-528.

[49] J.F. Reinganum, On the diffusion of new technology: A game theoretic approach, The Review of Economic Studies, 48 (1981) 395-405.

[50] T.H. Hannan, J.M. McDowell, The determinants of technology adoption: The case of the banking firm, The RAND Journal of Economics, (1984) 328-335.

[51] D. Fudenberg, J. Tirole, Preemption and rent equalization in the adoption of new technology, The Review of Economic Studies, 52 (1985) pp. 383-401.

[52] P.A. David, Clio and the Economics of QWERTY, The American economic review, 75 (1985) 332-337.

[53] S.R. Milliman, R. Prince, Firm incentives to promote technological change in pollution control, Journal of Environmental economics and Management, 17 (1989) 247-265.

[54] R.M. Cyert, J.G. March, A behavioral theory of the firm, Englewood Cliffs, NJ, 2 (1963).

[55] R.R. Nelson, N.Y.U.G.S.o.B.A.C.f. Science, T. Policy, Government and technical progress: a cross-industry analysis, Pergamon Press, 1982.

[56] M.L. Tushman, P. Anderson, Technological discontinuities and organizational environments, Administrative science quarterly, (1986) 439-465.

[57] J.W. Meyer, B. Rowan, Institutionalized organizations: Formal structure as myth and ceremony, American Journal of Sociology, (1977) pp. 340-363.

[58] P.S. Tolbert, L.G. Zucker, Institutional sources of change in the formal structure of organizations: The diffusion of civil service reform, 1880-1935, Administrative science quarterly, (1983) 22-39.

[59] P. Dimaggio, W. Powell, The iron cage revisited: Institutional isomorphism and collective rationality in organizational fields, American Sociological Review, 48 (1983) pp. 147-160.

[60] S. Bikhchandani, D. Hirshleifer, I. Welch, A theory of fads, fashion, custom, and cultural change as informational cascades, Journal of political Economy, 100 (1992) 992-1026.

[61] E. Abrahamson, L. Rosenkopf, Institutional and competitive bandwagons: Using mathematical modeling as a tool to explore innovation diffusion, Academy of management review, 18 (1993) 487-517.

[62] E. Abrahamson, L. Rosenkopf, Social network effects on the extent of innovation diffusion: A computer simulation, Organization science, 8 (1997) 289-309.

[63] M.C. Suchman, Managing legitimacy: Strategic and institutional approaches, Academy of Management Review, 20 (1995) 571-610.

[64] J.D. Westphal, R. Gulati, S.M. Shortell, Customization or conformity? An institutional and network perspective on the content and consequences of TQM adoption, Administrative science quarterly, (1997) 366-394.

[65] P.R. Haunschild, A.S. Miner, Modes of interorganizational imitation: The effects of outcome salience and uncertainty, Administrative science quarterly, (1997) 472-500.

[66] E. Abrahamson, G. Fairchild, Management fashion: Lifecycles, triggers, and collective learning processes, Administrative science quarterly, 44 (1999) 708-740.

[67] D.J. Teece, Profiting from technological innovation: Implications for integration, collaboration, licensing and public policy, Research Policy, 15 (1986) 285-305.

[68] J.A. Schumpeter, Socialism, capitalism and democracy, Harper and Brothers, 1942. 
[69] J.A. Schumpeter, The theory of economic development: An inquiry into profits, capital, credit, interest, and the business cycle, Transaction publishers, 1934.

[70] M.E. Porter, Competitive strategy: techniques for analyzing industries and competitors, New York: Free Press, 1980.

[71] R.M. Henderson, K.B. Clark, Architectural innovation: The reconfiguration of existing product technologies and the failure of established firms, Administrative science quarterly, (1990) 9-30.

[72] J. Barney, Firm resources and sustained competitive advantage, Journal of Management, 17 (1991) 99-120.

[73] J. Pfeffer, G.R. Salancik, The external control of organizations: a resource dependence perspective, Harper \& Row, 1978.

[74] M.L. Katz, C. Shapiro, Technology adoption in the presence of network externalities, The journal of political economy, (1986) pp. 822-841.

[75] G. Saloner, A. Shepard, Adoption of technologies with network effects: an empirical examination of the adoption of automated teller machines, in, National Bureau of Economic Research, 1992.

[76] M. Fishbein, I. Ajzen, Belief, attitude, intention and behavior: An introduction to theory and research, Reading, Mass. : Addison-Wesley, 1975., 1975.

[77] I. Ajzen, M. Fishbein, Understanding attitudes and predicting social behavior, PrenticeHall, 1980.

[78] I. Ajzen, The theory of planned behavior, Organizational behavior and human decision processes, 50 (1991) pp. 179-211.

[79] S. Taylor, P. Todd, Decomposition and crossover effects in the theory of planned behavior: A study of consumer adoption intentions, International journal of research in marketing, 12 (1995) pp. 137-155.

[80] F.D. Davis Jr, A technology acceptance model for empirically testing new end-user information systems: Theory and results, in, Massachusetts Institute of Technology, 1986.

[81] F.D. Davis, Perceived usefulness, perceived ease of use, and user acceptance of information technology, MIS quarterly, (1989) pp. 319-340.

[82] F.D. Davis, R.P. Bagozzi, P.R. Warshaw, User acceptance of computer technology: a comparison of two theoretical models, Management science, 35 (1989) pp. 982-1003.

[83] V. Venkatesh, F.D. Davis, A theoretical extension of the technology acceptance model: Four longitudinal field studies, Management science, 46 (2000) pp. 186-204.

[84] M.K. Chang, W. Cheung, Determinants of the intention to use Internet/WWW at work: a confirmatory study, Information \& Management, 39 (2001) pp. 1-14.

[85] G.C. Moore, I. Benbasat, Development of an instrument to measure the perceptions of adopting an information technology innovation, Information systems research, 2 (1991) pp. 192-222.

[86] R. Agarwal, J. Prasad, The role of innovation characteristics and perceived voluntariness in the acceptance of information technologies, Decision sciences, 28 (1997) pp. 557-582.

[87] R. Agarwal, J. Prasad, The antecedents and consequents of user perceptions in information technology adoption, Decision support systems, 22 (1998) pp. 15-29.

[88] E. Karahanna, D.W. Straub, N.L. Chervany, Information technology adoption across time: a cross-sectional comparison of pre-adoption and post-adoption beliefs, MIS quarterly, (1999) pp. 183-213.

[89] D.F. Midgley, G.R. Dowling, Innovativeness: The concept and its measurement, Journal of consumer research, 4 (1978) pp. 229-242.

[90] M.D. Dickerson, J.W. Gentry, Characteristics of adopters and non-adopters of home computers, Journal of Consumer research, (1983) pp. 225-235. 
[91] G. Roehrich, Consumer innovativeness: Concepts and measurements, Journal of Business Research, 57 (2004) 671-677.

[92] G.W. Downs Jr, L.B. Mohr, Conceptual issues in the study of innovation, Administrative science quarterly, (1976) pp. 700-714.

[93] J.R. Kimberly, M.J. Evanisko, Organizational innovation: The influence of individual, organizational, and contextual factors on hospital adoption of technological and administrative innovations, Academy of Management Journal, 24 (1981) pp. 689-713.

[94] R.D. Dewar, J.E. Dutton, The adoption of radical and incremental innovations: An empirical analysis, Management science, 32 (1986) pp. 1422-1433.

[95] A.D. Meyer, J.B. Goes, Organizational assimilation of innovations: a multilevel contextual analysis, Academy of Management Journal, 31 (1988) pp. 897-923.

[96] R.B. Cooper, R.W. Zmud, Information technology implementation research: a technological diffusion approach, Management science, 36 (1990) pp. 123-139.

[97] R.G. Fichman, C.F. Kemerer, Adoption of software engineering process innovations: The case of object orientation, Sloan management review, 34 (1993) pp. 7-22.

[98] J.Y.L. Thong, An integrated model of information systems adoption in small businesses, Journal of management information systems, 15 (1999) pp. 187-214.

[99] A. Jeyaraj, J.W. Rottman, M.C. Lacity, A review of the predictors, linkages, and biases in IT innovation adoption research, Journal of Information Technology, 21 (2006) 1-23.

[100] L.G. Tornatzky, M. Fleischer, A.K. Chakrabarti, Processes of technological innovation, Lexington Books, 1990.

[101] C.L. Iacovou, I. Benbasat, A.S. Dexter, Electronic data interchange and small organizations: Adoption and impact of technology, MIS quarterly, (1995) 465-485.

[102] P. Attewell, Technology diffusion and organizational learning: The case of business computing, Organization Science, 3 (1992) 1-19.

[103] D. Chatterjee, R. Grewal, V. Sambamurthy, Shaping up for e-commerce: institutional enablers of the organizational assimilation of web technologies, MIS quarterly, (2002) 65-89.

[104] R.G. Fichman, C.F. Kemerer, The illusory diffusion of innovation: An examination of assimilation gaps, Information systems research, 10 (1999) 255-275.

[105] P.Y. Chau, K.Y. Tam, Factors affecting the adoption of open systems: an exploratory study, MIS quarterly, (1997) 1-24.

[106] G. Zaltman, R. Duncan, J. Holbek, Innovations and organizations, Wiley New York, 1973.

[107] P. Chwelos, I. Benbasat, A.S. Dexter, Research report: Empirical test of an EDI adoption model, Information systems research, 12 (2001) 304-321.

[108] F. Damanpour, Organizational size and innovation, Organization studies, 13 (1992) pp. 375-402.

[109] G. Premkumar, K. Ramamurthy, S. Nilakanta, Implementation of electronic data interchange: an innovation diffusion perspective, Journal of Management Information Systems, 11 (1994) 157-186.

[110] G. Premkumar, K. Ramamurthy, The role of interorganizational and organizational factors on the decision mode for adoption of interorganizational systems, Decision sciences, 26 (1995) 303-336.

[111] F. Damanpour, M. Schneider, Phases of the adoption of innovation in organizations: Effects of environment, organization and top Managers1, British Journal of Management, 17 (2006) 215-236.

[112] G.H. Hofstede, G. Hofstede, Culture's consequences: Comparing values, behaviors, institutions and organizations across nations, Sage, 2001.

[113] B. Wejnert, Integrating models of diffusion of innovations: a conceptual framework, Annual review of sociology, (2002) 297-326. 
[114] R.G. Fichman, C.F. Kemerer, The assimilation of software process innovations: An organizational learning perspective, Management science, 43 (1997) 1345-1363.

[115] H. Gatignon, T.S. Robertson, Technology diffusion: an empirical test of competitive effects, The Journal of Marketing, (1989) pp. 35-49.

[116] E.E. Grandon, J.M. Pearson, Electronic commerce adoption: an empirical study of small and medium US businesses, Information \& management, 42 (2004) 197-216.

[117] G. Premkumar, M. Roberts, Adoption of new information technologies in rural small businesses, Omega, 27 (1999) 467-484.

[118] V. Grover, An empirically derived model for the adoption of customer-based interorganizational systems, Decision sciences, 24 (1993) 603-640.

[119] E.B. Swanson, N.C. Ramiller, Innovating mindfully with information technology, MIS quarterly, (2004) 553-583.

[120] K.K. Kuan, P.Y. Chau, A perception-based model for EDI adoption in small businesses using a technology-organization-environment framework, Information \& management, 38 (2001) 507-521.

[121] H. Liang, N. Saraf, Q. Hu, Y. Xue, Assimilation of enterprise systems: the effect of institutional pressures and the mediating role of top management, MIS quarterly, (2007) 5987.

[122] T.S. Teo, S.H. Pok, Adoption of WAP-enabled mobile phones among Internet users, Omega, 31 (2003) pp. 483-498.

[123] K. Zhu, K. Kraemer, S. Xu, Electronic business adoption by European firms: a crosscountry assessment of the facilitators and inhibitors, European Journal of Information Systems, 12 (2003) 251-268.

[124] K. Zhu, K.L. Kraemer, Post-adoption variations in usage and value of e-business by organizations: cross-country evidence from the retail industry, Information systems research, 16 (2005) 61-84.

[125] K. Zhu, K.L. Kraemer, V. Gurbaxani, S.X. Xu, Migration to open-standard interorganizational systems: Network effects, switching costs, and path dependency, Mis Quarterly, 30 (2006) 515-539.

[126] V. Mahajan, E. Muller, F.M. Bass, New product diffusion models in marketing: A review and directions for research, The Journal of Marketing, (1990) pp. 1-26.

[127] J.A. Norton, F.M. Bass, A diffusion theory model of adoption and substitution for successive generations of high-technology products, Management science, 33 (1987) pp. 10691086.

[128] C. Van den Bulte, Y.V. Joshi, New product diffusion with Influentials and imitators, Marketing Science, 26 (2007) pp. 400-421.

[129] C. Van den Bulte, G.L. Lilien, Medical Innovation Revisited: Social Contagion versus Marketing Effort 1, American Journal of Sociology, 106 (2001) 1409-1435.

[130] C. Van den Bulte, S. Stremersch, Social contagion and income heterogeneity in new product diffusion: A meta-analytic test, Marketing Science, 23 (2004) pp. 530-544.

[131] R.A. Chatterjee, J. Eliashberg, The innovation diffusion process in a heterogeneous population: A micromodeling approach, Management science, 36 (1990) pp. 1057-1079.

[132] G.J. Tellis, S. Stremersch, E. Yin, The international takeoff of new products: The role of economics, culture, and country innovativeness, Marketing science, 22 (2003) 188-208.

[133] F. Sultan, J.U. Farley, D.R. Lehmann, A meta-analysis of applications of diffusion models, Journal of marketing research, (1990) pp. 70-77.

[134] V. Mahajan, E. Muller, Y. Wind, New-product diffusion models, Springer, 2000.

[135] N. Meade, T. Islam, Modelling and forecasting the diffusion of innovation-A 25-year review, International Journal of forecasting, 22 (2006) 519-545. 
[136] R. Peres, E. Muller, V. Mahajan, Innovation diffusion and new product growth models: A critical review and research directions, International journal of research in marketing, 27 (2010) 91-106.

[137] G. Feder, D.L. Umali, The adoption of agricultural innovations: a review, Technological forecasting and social change, 43 (1993) pp. 215-239.

[138] A.D. Foster, M.R. Rosenzweig, Learning by doing and learning from others: Human capital and technical change in agriculture, Journal of political Economy, (1995) pp. 11761209.

[139] M.S. Granovetter, The strength of weak ties, American Journal of Sociology, (1973) $1360-1380$.

[140] R.S. Burt, Social contagion and innovation: Cohesion versus structural equivalence, American Journal of Sociology, (1987) 1287-1335.

[141] A. Molla, P.S. Licker, eCommerce adoption in developing countries: a model and instrument, Information \& Management, 42 (2005) pp. 877-899.

[142] A. Molla, P.S. Licker, Perceived e-readiness factors in e-commerce adoption: An empirical investigation in a developing country, International Journal of Electronic Commerce, 10 (2005) pp. 83-110.

[143] S. Bruque, J. Moyano, Organisational determinants of information technology adoption and implementation in SMEs: The case of family and cooperative firms, Technovation, 27 (2007) pp. 241-253.

[144] S.-Y. Hung, C.C. Chen, W.-J. Lee, Moving hospitals toward e-learning adoption: an empirical investigation, Journal of Organizational Change Management, 22 (2009) pp. 239256.

[145] Y.-M. Wang, Y.-S. Wang, Y.-F. Yang, Understanding the determinants of RFID adoption in the manufacturing industry, Technological Forecasting and Social Change, 77 (2010) pp. 803-815.

[146] W.Y. Hong, K. Zhu, Migrating to internet-based e-commerce: Factors affecting ecommerce adoption and migration at the firm level, Information \& Management, 43 (2006) pp. 204-221.

[147] K.A. Patterson, C.M. Grimm, T.M. Corsi, Adopting new technologies for supply chain management, Transportation Research Part E-Logistics and Transportation Review, 39 (2003) pp. 95-121.

[148] A.R. Del Aguila-Obra, A. Padilla-Melendez, Organizational factors affecting Internet technology adoption, Internet Research, 16 (2006) pp. 94-110.

[149] W. Lewis, R. Agarwal, V. Sambamurthy, Sources of influence on beliefs about information technology use: An empirical study of knowledge workers, Mis Quarterly, 27 (2003) pp. 657-678.

[150] G.C. Bruner, A. Kumar, Explaining consumer acceptance of handheld Internet devices, Journal of Business Research, 58 (2005) pp. 553-558.

[151] J.H. Wu, S.C. Wang, What drives mobile commerce? An empirical evaluation of the revised technology acceptance model, Information \& Management, 42 (2005) 719-729.

[152] S.J. Hong, K.Y. Tam, Understanding the adoption of multipurpose information appliances: The case of mobile data services, Information Systems Research, 17 (2006) pp. 162-179.

[153] T.S.H. Teo, S.H. Pok, Adoption of WAP-enabled mobile phones among Internet users, Omega-International Journal of Management Science, 31 (2003) pp. 483-498.

[154] E. Karahanna, R. Agarwal, C.M. Angst, Reconceptualizing compatibility beliefs in technology acceptance research, Mis Quarterly, 30 (2006) 781-804. 
[155] C.-L. Hsu, H.-P. Lu, H.-H. Hsu, Adoption of the mobile Internet: An empirical study of multimedia message service (MMS), Omega-International Journal of Management Science, 35 (2007) pp. 715-726.

[156] T.F. Bresnahan, M. Trajtenberg, General purpose technologies 'Engines of growth'?, Journal of econometrics, 65 (1995) 83-108.

[157] S. Fabiani, F. Schivardi, S. Trento, ICT adoption in Italian manufacturing: firm-level evidence, Industrial and Corporate Change, 14 (2005) 225-249.

[158] M.P. Feldman, D.F. Kogler, D.L. Rigby, rKnowledge: the spatial diffusion and adoption of rDNA methods, Regional studies, 49 (2015) 798-817.

[159] T. Åstebro, Sunk costs and the depth and probability of technology adoption, The Journal of Industrial Economics, 52 (2004) 381-399.

[160] L. Fuentelsaz, J. Gómez, S. Palomas, The effects of new technologies on productivity: An intrafirm diffusion-based assessment, Research Policy, 38 (2009) 1172-1180.

[161] L. Fuentelsaz, J. Gomez, Y. Polo, Intrafirm diffusion of new technologies: an empirical application, Research Policy, 32 (2003) 533-551.

[162] G. Battisti, P. Stoneman, The intra-firm diffusion of new process technologies, International Journal of Industrial Organization, 23 (2005) 1-22.

[163] H. Hollenstein, M. Woerter, Inter-and intra-firm diffusion of technology: The example of E-commerce: An analysis based on Swiss firm-level data, Research Policy, 37 (2008) 545564.

[164] P. Milgrom, J. Roberts, Rationalizability, learning, and equilibrium in games with strategic complementarities, Econometrica: Journal of the Econometric Society, (1990) 12551277.

[165] P. Milgrom, J. Roberts, Complementarities and fit strategy, structure, and organizational change in manufacturing, Journal of accounting and economics, 19 (1995) 179-208.

[166] R. Bocquet, O. Brossard, M. Sabatier, Complementarities in organizational design and the diffusion of information technologies: An empirical analysis, Research Policy, 36 (2007) 367-386.

[167] J. Gomez, P. Vargas, The effect of financial constraints, absorptive capacity and complementarities on the adoption of multiple process technologies, Research Policy, 38 (2009) 106-119.

[168] A. Arora, C. Forman, J.W. Yoon, Complementarity and information technology adoption: Local area networks and the Internet, Information Economics and Policy, 22 (2010) 228-242.

[169] M.G. Colombo, A. Croce, L. Grilli, ICT services and small businesses' productivity gains: An analysis of the adoption of broadband Internet technology, Information Economics and Policy, 25 (2013) 171-189.

[170] A. BEN-NER, S. Lluis, Learning: what and how? An empirical study of adjustments in workplace organization structure, Industrial Relations: A Journal of Economy and Society, 50 (2011) 76-108.

[171] R.J. Kauffman, X. Li, Technology competition and optimal investment timing: a real options perspective, IEEE Transactions on Engineering Management, 52 (2005) 15-29.

[172] X. Li, Preemptive learning, competency traps, and information technology adoption: a real options analysis, IEEE Transactions on Engineering Management, 56 (2009) 650-662.

[173] C. Forman, The corporate digital divide: Determinants of Internet adoption, Management Science, 51 (2005) pp. 641-654.

[174] F.F. Suarez, Network effects revisited: The role of strong ties in technology selection, Academy of Management Journal, 48 (2005) pp. 710-720.

[175] L. Fuentelsaz, J. Gomez, Y. Polo, Intrafirm diffusion of new technologies: an empirical application, Research Policy, 32 (2003) pp. 533-551. 
[176] J. Bourke, S. Roper, In with the new: the determinants of prescribing innovation by general practitioners in Ireland, European Journal of Health Economics, 13 (2012) pp. 393407.

[177] F. Schivardi, M. Schneider, Strategic experimentation and disruptive technological change, Review of Economic Dynamics, 11 (2008) 386-412.

[178] F. Lissoni, The reaper and the scanner: indivisibility-led incremental innovations and the adoption of new technologies, Cambridge Journal of Economics, 29 (2005) 359-379.

[179] T. Requate, W. Unold, Environmental policy incentives to adopt advanced abatement technology: Will the true ranking please stand up?, European Economic Review, 47 (2003) pp. 125-146.

[180] T. Requate, Dynamic incentives by environmental policy instruments - a survey, Ecological Economics, 54 (2005) pp. 175-195.

[181] T. Requate, Timing and commitment of environmental policy, adoption of new technology, and repercussions on R\&D, Environmental \& Resource Economics, 31 (2005) pp. 175-199.

[182] A.B. Jaffe, R.G. Newell, R.N. Stavins, A tale of two market failures: Technology and environmental policy, Ecological Economics, 54 (2005) pp. 164-174.

[183] S. Kerr, R.G. Newell, Policy-induced technology adoption: Evidence from the US lead phasedown, Journal of Industrial Economics, 51 (2003) 317-343.

[184] M.R. Taylor, E.S. Rubin, D.A. Hounshell, Control of SO2 emissions from power plants: A case of induced technological innovation in the US, Technological Forecasting and Social Change, 72 (2005) pp. 697-718.

[185] M. Beise, Lead markets: country-specific drivers of the global diffusion of innovations, Research Policy, 33 (2004) pp. 997-1018.

[186] M. Beise, K. Rennings, Lead markets and regulation: a framework for analyzing the international diffusion of environmental innovations, Ecological Economics, 52 (2005) pp. 517.

[187] A.A. Erumban, S.B. de Jong, Cross-country differences in ICT adoption: A consequence of Culture?, Journal of World Business, 41 (2006) pp. 302-314.

[188] A. Davila, G. Foster, M. Li, Reasons for management control systems adoption: Insights from product development systems choice by early-stage entrepreneurial companies, Accounting Organizations and Society, 34 (2009) pp. 322-347.

[189] D.O. Kim, J. Bae, Workplace innovation, employment relations and HRM: two electronics companies in South Korea, International Journal of Human Resource Management, 16 (2005) pp. 1277-1302.

[190] C. Jaca, J. Santos, A. Errasti, E. Viles, Lean thinking with improvement teams in retail distribution: a case study, Total Quality Management \& Business Excellence, 23 (2012) pp. 449-465.

[191] J.E. Lervik, R. Lunnan, Contrasting perspectives on the diffusion of management knowledge - Performance management in a Norwegian multinational, Management Learning, 35 (2004) pp. 287-302.

[192] E. Daniel, A. Myers, K. Dixon, Adoption rationales of new management practices, Journal of Business Research, 65 (2012) 371-380.

[193] A. Compagni, V. Mele, D. Ravasi, How early implementations influence later adoptions of innovation: Social positioning and skill reproduction in the diffusion of robotic surgery, Academy of Management Journal, 58 (2015) 242-278.

[194] J. Birkinshaw, G. Hamel, M.J. Mol, Management innovation, Academy of management Review, 33 (2008) 825-845. 
[195] S. Khanagha, H. Volberda, J. Sidhu, I. Oshri, Management innovation and adoption of emerging technologies: The case of cloud computing, European Management Review, 10 (2013) 51-67.

[196] H.-F. Lin, J.-Q. Su, A. Higgins, How dynamic capabilities affect adoption of management innovations, Journal of Business Research, 69 (2016) 862-876.

[197] H.R. Greve, Fast and expensive: The diffusion of a disappointing innovation, Strategic Management Journal, 32 (2011) pp. 949-968.

[198] I. Barreto, C. Baden-Fuller, To conform or to perform? Mimetic behaviour, legitimacybased groups and performance consequences, Journal of Management Studies, 43 (2006) pp. 1559-1581.

[199] T. Reay, S. Chreim, K. Golden-Biddle, E. Goodrick, B.E. Williams, A. Casebeer, A. Pablo, C. Hinings, Transforming new ideas into practice: An activity based perspective on the institutionalization of practices, Journal of Management Studies, 50 (2013) 963-990.

[200] J. O'Mahoney, The diffusion of management innovations: The possibilities and limitations of memetics, Journal of Management Studies, 44 (2007) 1324-1348.

[201] H.-L. Cheng, Seeking knowledge or gaining legitimacy? Role of social networks on new practice adoption by OEM suppliers, Journal of Business Research, 63 (2010) pp. 824-831.

[202] E.G. Love, P. Cebon, Meanings on multiple levels: The influence of field-level and organizational-level meaning systems on diffusion, Journal of Management Studies, 45 (2008) pp. 239-267.

[203] N.C. Ramiller, E.B. Swanson, Organizing visions for information technology and the information systems executive response, Journal of Management Information Systems, 20 (2003) pp. 13-50.

[204] D. Etzion, F. Ferraro, The Role of Analogy in the Institutionalization of Sustainability Reporting, Organization Science, 21 (2010) pp. 1092-1107.

[205] E. Daniel, A. Myers, K. Dixon, Adoption rationales of new management practices, Journal of Business Research, 65 (2012) pp. 371-380.

[206] E. Abrahamson, Management fashion, Academy of Management Review, 21 (1996) pp. 254-285.

[207] R.L. Baskerville, M.D. Myers, FASHION WAVES IN INFORMATION SYSTEMS RESEARCH AND PRACTICE, Mis Quarterly, 33 (2009) pp. 647-662.

[208] P. Wang, CHASING THE HOTTEST IT: EFFECTS OF INFORMATION TECHNOLOGY FASHION ON ORGANIZATIONS, Mis Quarterly, 34 (2010) pp. 63-85.

[209] S. Basaglia, L. Caporarello, M. Magni, F. Pennarola, Environmental and organizational drivers influencing the adoption of VoIP, Information Systems and E-Business Management, 7 (2009) pp. 103-118.

[210] S. Massini, A.Y. Lewin, H.R. Greve, Innovators and imitators: Organizational reference groups and adoption of organizational routines, Research Policy, 34 (2005) pp. 1550-1569.

[211] R.P. Lee, R. Grewal, Strategic responses to new technologies and their impact on firm performance, Journal of Marketing, 68 (2004) pp. 157-171.

[212] H.R. Greve, Bigger and safer: The diffusion of a competitive advantage, Strategic Management Journal, 30 (2009) pp. 1-23.

[213] F. Damanpour, R.M. Walker, C.N. Avellaneda, Combinative effects of innovation types and organizational performance: A longitudinal study of service organizations, Journal of Management Studies, 46 (2009) pp. 650-675.

[214] F.M. Bass, T.V. Krishnan, D.C. Jain, Why the Bass model fits without decision variables, Marketing science, 13 (1994) pp. 203-223.

[215] A. Prasad, V. Mahajan, How many pirates should a software firm tolerate? An analysis of piracy protection on the diffusion of software, International Journal of Research in Marketing, 20 (2003) pp. 337-353. 
[216] F. Centrone, A. Goia, E. Salinelli, Demographic processes in a model of innovation diffusion with a dynamic market, Technological Forecasting and Social Change, 74 (2007) pp. 247-266.

[217] R. Guseo, M. Guidolin, Modelling a dynamic market potential: A class of automata networks for diffusion of innovations, Technological Forecasting and Social Change, 76 (2009) pp. 806-820.

[218] R. Guseo, M. Guidolin, Market potential dynamics in innovation diffusion: Modelling the synergy between two driving forces, Technological Forecasting and Social Change, 78 (2011) pp. 13-24.

[219] J.H. Pae, D.R. Lehmann, Multigeneration innovation diffusion: The impact of intergeneration time, Journal of the Academy of Marketing Science, 31 (2003) pp. 36-45.

[220] Y. Orbach, G.E. Fruchter, Forecasting sales and product evolution: The case of the hybrid/electric car, Technological Forecasting and Social Change, 78 (2011) pp. 1210-1226.

[221] H. Rahmandad, J. Sterman, Heterogeneity and network structure in the dynamics of diffusion: Comparing agent-based and differential equation models, Management Science, 54 (2008) pp. 998-1014.

[222] P. Manchanda, Y. Xie, N. Youn, The Role of Targeted Communication and Contagion in Product Adoption, Marketing Science, 27 (2008) pp. 961-976.

[223] H.P. Young, Innovation Diffusion in Heterogeneous Populations: Contagion, Social Influence, and Social Learning, American Economic Review, 99 (2009) 1899-1924.

[224] R. Iyengar, C. Van den Bulte, T.W. Valente, Opinion Leadership and Social Contagion in New Product Diffusion, Marketing Science, 30 (2011) pp. 195-212.

[225] C. Schlereth, C. Barrot, B. Skiera, C. Takac, Optimal Product-Sampling Strategies in Social Networks: How Many and Whom to Target?, International Journal of Electronic Commerce, 18 (2013) pp. 45-72.

[226] T. Garber, J. Goldenberg, B. Libai, E. Muller, From density to destiny: Using spatial dimension of sales data for early prediction of new product success, Marketing Science, 23 (2004) pp. 419-428.

[227] A. De Bruyn, G.L. Lilien, A multi-stage model of word-of-mouth influence through viral marketing, International Journal of Research in Marketing, 25 (2008) pp. 151-163.

[228] Y.M. Van Everdingen, The effect of national culture on the adoption of innovations, Marketing Letters, 14 (2003) pp. 217-232.

[229] Y. van Everdingen, D. Fok, S. Stremersch, Modeling Global Spillover of New Product Takeoff, Journal of Marketing Research, 46 (2009) pp. 637-652.

[230] S. Sundqvist, L. Frank, K. Puumalainen, The effects of country characteristics, cultural similarity and adoption timing on the diffusion of wireless communications, Journal of Business Research, 58 (2005) pp. 107-110.

[231] M. Fornerino, Internet adoption in France, Service Industries Journal, 23 (2003) pp. 119135.

[232] C.J. Easingwood, V. Mahajan, E. Muller, A nonuniform influence innovation diffusion model of new product acceptance, Marketing Science, 2 (1983) pp. 273-295.

[233] M. Burton, D. Rigby, T. Young, Modelling the adoption of organic horticultural technology in the UK using duration analysis, Australian Journal of Agricultural and Resource Economics, 47 (2003) 29-54.

[234] F.H. D'Emden, R.S. Llewellyn, M.P. Burton, Adoption of conservation tillage in Australian cropping regions: An application of duration analysis, Technological Forecasting and Social Change, 73 (2006) pp. 630-647.

[235] G.R. Marshall, Polycentricity, reciprocity, and farmer adoption of conservation practices under community-based governance, Ecological Economics, 68 (2009) 1507-1520. 
[236] P. Koundouri, C. Nauges, V. Tzouvelekas, Technology adoption under production uncertainty: Theory and application to irrigation technology, American Journal of Agricultural Economics, 88 (2006) pp. 657-670.

[237] P.P. Marenya, C.B. Barrett, Household-level determinants of adoption of improved natural resources management practices among smallholder farmers in western Kenya, Food Policy, 32 (2007) pp. 515-536.

[238] C. Carletto, A. Kirk, P.C. Winters, B. Davis, Globalization and Smallholders: The Adoption, Diffusion, and Welfare Impact of Non-Traditional Export Crops in Guatemala, World Development, 38 (2010) pp. 814-827.

[239] D. Laepple, Adoption and Abandonment of Organic Farming: An Empirical Investigation of the Irish Drystock Sector, Journal of Agricultural Economics, 61 (2010) pp. 697-714.

[240] S.W. Davies, Inter-firm diffusion of process innovations, European Economic Review, 12 (1979) pp. 299-317.

[241] T.G. Conley, C.R. Udry, Learning about a New Technology: Pineapple in Ghana, American Economic Review, 100 (2010) pp. 35-69.

[242] A. Diagne, M. Demont, Taking a new look at empirical models of adoption: average treatment effect estimation of adoption rates and their determinants, Agricultural Economics, 37 (2007) pp. 201-210.

[243] C.R. Doss, Analyzing technology adoption using microstudies: limitations, challenges, and opportunities for improvement, Agricultural Economics, 34 (2006) pp. 207-219.

[244] G. Wong, T. Greenhalgh, R. Pawson, Internet-based medical education: a realist review of what works, for whom and in what circumstances, BMC medical education, 10 (2010) 12.

[245] J.P. Wisdom, K.H.B. Chor, K.E. Hoagwood, S.M. Horwitz, Innovation adoption: a review of theories and constructs, Administration and Policy in Mental Health and Mental Health Services Research, 41 (2014) 480-502.

[246] K.K. Kapoor, Y.K. Dwivedi, M.D. Williams, Rogers’ innovation adoption attributes: a systematic review and synthesis of existing research, Information Systems Management, 31 (2014) 74-91.

[247] P. Sriwannawit, U. Sandström, Large-scale bibliometric review of diffusion research, Scientometrics, 102 (2015) 1615-1645.

[248] L. Aarikka-Stenroos, B. Sandberg, T. Lehtimäki, Networks for the commercialization of innovations: A review of how divergent network actors contribute, Industrial Marketing Management, 43 (2014) 365-381.

[249] J. Innis, K. Dryden-Palmer, T. Perreira, W. Berta, How do health care organizations take on best practices? A scoping literature review, International journal of evidence-based healthcare, 13 (2015) 254-272.

[250] L.-D. Radu, Determinants of Green ICT adoption in organizations: A theoretical perspective, Sustainability, 8 (2016) 731.

[251] N. Adnan, S.M. Nordin, I. Rahman, Adoption of PHEV/EV in Malaysia: a critical review on predicting consumer behaviour, Renewable and Sustainable Energy Reviews, 72 (2017) 849-862.

[252] N. Adnan, S.M. Nordin, I. Rahman, M.H. Amini, A market modeling review study on predicting Malaysian consumer behavior towards widespread adoption of PHEV/EV, Environmental Science and Pollution Research, 24 (2017) 17955-17975.

[253] N. Adnan, S.M. Nordin, I. Rahman, P.M. Vasant, A. Noor, A comprehensive review on theoretical framework-based electric vehicle consumer adoption research, International Journal of Energy Research, 41 (2017) 317-335. 
[254] S. Rahbauer, L. Menapace, K. Menrad, T. Decker, Adoption of green electricity by smalland medium-sized enterprises in Germany, Renewable and Sustainable Energy Reviews, 59 (2016) 1185-1194.

[255] J.D. Allen, S.D. Towne, A.E. Maxwell, L. DiMartino, B. Leyva, D.J. Bowen, L. Linnan, B.J. Weiner, Measures of organizational characteristics associated with adoption and/or implementation of innovations: A systematic review, BMC health services research, 17 (2017) 591.

[256] E. Karakaya, P. Sriwannawit, Barriers to the adoption of photovoltaic systems: The state of the art, Renewable and Sustainable Energy Reviews, 49 (2015) 60-66.

[257] N.P. Rana, Y.K. Dwivedi, M.D. Williams, A meta-analysis of existing research on citizen adoption of e-government, Information Systems Frontiers, 17 (2015) 547-563.

[258] M.B. Bossle, M.D. de Barcellos, L.M. Vieira, L. Sauvée, The drivers for adoption of ecoinnovation, Journal of Cleaner Production, 113 (2016) 861-872.

[259] E. Karakaya, A. Hidalgo, C. Nuur, Diffusion of eco-innovations: A review, Renewable and Sustainable Energy Reviews, 33 (2014) 392-399.

[260] Z. Rezvani, J. Jansson, J. Bodin, Advances in consumer electric vehicle adoption research: A review and research agenda, Transportation research part D: transport and environment, 34 (2015) 122-136.

[261] T. Byambaa, C. Janes, T. Takaro, K. Corbett, Putting health impact assessment into practice through the lenses of diffusion of innovations theory: a review, Environment, development and sustainability, 17 (2015) 23-40.

[262] P. Kelly, J. Hegarty, J. Barry, K.R. Dyer, A. Horgan, A systematic review of the relationship between staff perceptions of organizational readiness to change and the process of innovation adoption in substance misuse treatment programs, Journal of substance abuse treatment, 80 (2017) 6-25.

[263] N. Sanakulov, H. Karjaluoto, Consumer adoption of mobile technologies: a literature review, International Journal of Mobile Communications, 13 (2015) 244-275.

[264] B. Candas, G. Jobin, C. Dubé, M. Tousignant, A.B. Abdeljelil, S. Grenier, M.-P. Gagnon, Barriers and facilitators to implementing continuous quality improvement programs in colonoscopy services: a mixed methods systematic review, Endoscopy international open, 4 (2016) E118.

[265] V. Khanassov, I. Vedel, P. Pluye, Case management for dementia in primary health care: a systematic mixed studies review based on the diffusion of innovation model, Clinical interventions in aging, 9 (2014) 915.

[266] B.K. Sovacool, D.J. Hess, Ordering theories: Typologies and conceptual frameworks for sociotechnical change, Social studies of science, 47 (2017) 703-750.

[267] K. Cresswell, A. Sheikh, Organizational issues in the implementation and adoption of health information technology innovations: an interpretative review, International journal of medical informatics, 82 (2013) e73-e86.

[268] P.C.B. Khong, E. Holroyd, W. Wang, A critical review of the theoretical frameworks and the conceptual factors in the adoption of clinical decision support systems, CIN: Computers, Informatics, Nursing, 33 (2015) 555-570.

[269] C. De Grood, A. Raissi, Y. Kwon, M.J. Santana, Adoption of e-health technology by physicians: a scoping review, Journal of multidisciplinary healthcare, 9 (2016) 335.

[270] C.S. Kruse, J. DeShazo, F. Kim, L. Fulton, Factors associated with adoption of health information technology: a conceptual model based on a systematic review, JMIR medical informatics, 2 (2014).

[271] S.J. Tayouga, S.A. Gagné, The Socio-Ecological Factors that Influence the Adoption of Green Infrastructure, Sustainability, 8 (2016) 1277. 
[272] O. Ellabban, H. Abu-Rub, Smart grid customers' acceptance and engagement: An overview, Renewable and Sustainable Energy Reviews, 65 (2016) 1285-1298.

[273] M. Lefebvre, S.R. Langrell, S. Gomez-y-Paloma, Incentives and policies for integrated pest management in Europe: a review, Agronomy for sustainable development, 35 (2015) 2745.

[274] Y. Varabyova, C.R. Blankart, A.L. Greer, J. Schreyögg, The determinants of medical technology adoption in different decisional systems: A systematic literature review, Health Policy, 121 (2017) 230-242.

[275] K.S. Estem, J. Catania, J.D. Klausner, HIV self-testing: a review of current implementation and fidelity, Current HIV/AIDS Reports, 13 (2016) 107-115.

[276] G. Lyle, Understanding the nested, multi-scale, spatial and hierarchical nature of future climate change adaptation decision making in agricultural regions: a narrative literature review, Journal of Rural Studies, 37 (2015) 38-49.

[277] M.D. Williams, N.P. Rana, Y.K. Dwivedi, The unified theory of acceptance and use of technology (UTAUT): a literature review, Journal of Enterprise Information Management, 28 (2015) 443-488.

[278] M.-P. Gagnon, P. Ngangue, J. Payne-Gagnon, M. Desmartis, m-Health adoption by healthcare professionals: a systematic review, Journal of the American Medical Informatics Association, 23 (2015) 212-220.

[279] M. Moglia, S. Cook, J. McGregor, A review of Agent-Based Modelling of technology diffusion with special reference to residential energy efficiency, Sustainable Cities and Society, 31 (2017) 173-182.

[280] H. Gangwar, H. Date, A. Raoot, Review on IT adoption: insights from recent technologies, Journal of Enterprise Information Management, 27 (2014) 488-502.

[281] S. Molinillo, A. Japutra, Organizational adoption of digital information and technology: a theoretical review, The Bottom Line, 30 (2017) 33-46.

[282] C.-C. Wu, Status quo bias in information system adoption: a meta-analytic review, Online Information Review, 40 (2016) 998-1017.

[283] P. Goodwin, S. Meeran, K. Dyussekeneva, The challenges of pre-launch forecasting of adoption time series for new durable products, International Journal of Forecasting, 30 (2014) 1082-1097.

[284] A.R. Montazemi, H. Qahri-Saremi, Factors affecting adoption of online banking: A metaanalytic structural equation modeling study, Information \& Management, 52 (2015) 210-226.

[285] D.E. Yeatts, D. Auden, C. Cooksey, C.-F. Chen, A systematic review of strategies for overcoming the barriers to energy-efficient technologies in buildings, Energy Research \& Social Science, 32 (2017) 76-85.

[286] P. Hanafizadeh, B.W. Keating, H.R. Khedmatgozar, A systematic review of Internet banking adoption, Telematics and informatics, 31 (2014) 492-510.

[287] J. Mwirigi, B.B. Balana, J. Mugisha, P. Walekhwa, R. Melamu, S. Nakami, P. Makenzi, Socio-economic hurdles to widespread adoption of small-scale biogas digesters in Sub-Saharan Africa: A review, biomass and bioenergy, 70 (2014) 17-25.

[288] G. Zanello, X. Fu, P. Mohnen, M. Ventresca, The creation and diffusion of innovation in developing countries: a systematic literature review, Journal of Economic Surveys, 30 (2016) 884-912.

[289] K. Hasler, H.-W. Olfs, O. Omta, S. Bröring, Drivers for the Adoption of Different EcoInnovation Types in the Fertilizer Sector: A Review, Sustainability, 9 (2017) 2216.

[290] M.G. Nejad, D.L. Sherrell, E. Babakus, Influentials and influence mechanisms in new product diffusion: an integrative review, Journal of Marketing Theory and Practice, 22 (2014) 185-208. 
[291] H. Zhang, X. Xu, J. Xiao, Diffusion of e-government: A literature review and directions for future directions, Government Information Quarterly, 31 (2014) 631-636.

[292] J. Hojnik, M. Ruzzier, What drives eco-innovation? A review of an emerging literature, Environmental Innovation and Societal Transitions, 19 (2016) 31-41.

[293] D.K. Novins, A.E. Green, R.K. Legha, G.A. Aarons, Dissemination and implementation of evidence-based practices for child and adolescent mental health: A systematic review, Journal of the American Academy of Child \& Adolescent Psychiatry, 52 (2013) 1009-1025. e1018.

[294] T. Ingebrigtsen, A. Georgiou, R. Clay-Williams, F. Magrabi, A. Hordern, M. Prgomet, J. Li, J. Westbrook, J. Braithwaite, The impact of clinical leadership on health information technology adoption: Systematic review, International journal of medical informatics, 83 (2014) 393-405.

[295] W. Ortiz, J. Terrapon-Pfaff, C. Dienst, Understanding the diffusion of domestic biogas technologies. Systematic conceptualisation of existing evidence from developing and emerging countries, Renewable and Sustainable Energy Reviews, 74 (2017) 1287-1299.

[296] H.D. White, K.W. McCain, Visualizing a discipline: An author co-citation analysis of information science, 1972-1995, Journal of the American society for information science, 49 (1998) 327-355.

[297] M.P. Hekkert, R.A. Suurs, S.O. Negro, S. Kuhlmann, R.E. Smits, Functions of innovation systems: A new approach for analysing technological change, Technological forecasting and social change, 74 (2007) 413-432.

[298] F.W. Geels, J. Schot, Typology of sociotechnical transition pathways, Research Policy, 36 (2007) 399-417.

[299] D.F. Schraven, A. Hartmann, G.P. Dewulf, Research orientations towards the 'management'of infrastructure assets: an intellectual structure approach, Structure and infrastructure engineering, 11 (2015) 73-96. 